\title{
Understanding the relationships between information technology and lean and agile supply chain strategies: a systematic literature review
}

\author{
Diéssica Oliveira-Dias $^{1}$ (D) José Moyano-Fuentes ${ }^{1}$ (D) \\ Juan Manuel Maqueira-Marín ${ }^{1}$
}

Accepted: 3 January 2022 / Published online: 19 January 2022

(c) The Author(s) 2022

\begin{abstract}
This study analyzes the relationships studied in the literature between Information Technologies (IT) and two supply chain strategies that have similar mechanisms of action: Lean Supply Chain (LSC) and Agile Supply Chain (ASC). The purpose is to identify and understand the role that IT plays in the two strategies depending on the way that it is conceptualized, and whether this is transferred to performance. The Systematic Literature Review is the methodology used to locate articles, select and analyze their content. In general terms, research to date shows a positive association between IT and these two supply chain strategies and that this association improves business results. However, the study shows that research into LSC and ASC has used different conceptualizations of IT and, in some cases, these conceptualizations can have different effects on the study's outcomes. This paper proposes directions for future research and theoretical development are suggested.
\end{abstract}

Keywords Information technologies · Lean supply chain · Agile supply chain - Systematic literature review

\section{Introduction}

There is a broad consensus in the literature that supports the statement that for a company to be competitive at the current time, it should not only focus on internal aspects, but also manage its supply chain (SC) efficiently and effectively. As a result, the principles of Lean management and Agile manufacturing have been incorporated into supply chain management (SCM) in

Diéssica Oliveira-Dias

oliveira@ujaen.es

José Moyano-Fuentes

jmoyano@ujaen.es

Juan Manuel Maqueira-Marín

maqueira@ujaen.es

1 Department of Business Organization, Marketing and Sociology, EPS Linares, University of Jaen, 23700 Linares, Jaen, Spain 
recent decades. This has given rise to the Lean Supply Chain strategy (LSC) (Lamming, 1996) and the Agile Supply Chain strategy (ASC) (Christopher, 2000). LSC strategy focuses on the elimination of waste and non-value added activities across the supply chain and is associated with level scheduling in an environment of low uncertainty, while ASC strategy focuses on the ability to meet market requirements and requires capacity to be set aside to handle volatile demand (Christopher, 2000; Qrunfleh \& Tarafdar, 2014).

However, supply chains are becoming more complex and managing such complexity to provide effective responsiveness increasingly requires adequate and intelligent information processing (Kharub et al., 2019; Qrunfleh \& Tarafdar, 2014). In this sense, Information Technology (IT) is a tool that plays a major role in the digitalization and/or development of information management processes at the SC level in the pursuit of responsiveness-related competitive advantages (Calatayud et al., 2019; Zhang et al., 2011). Therefore, since LSC and ASC are strategies related to SC's responsiveness capability, providing, respectively, leanness or agility (Qrunfleh \& Tarafdar, 2013) to it, both SC strategies can be supported by IT. Indeed, new developments in IT solutions that can be applied to SC and changes in demand that require very flexible responses have driven up business management interest in the IT-flexibility relationship and inspired researchers to analyze the existing relationship between IT and Lean practices at the SC level (Moyano-Fuentes et al., 2012; Pagliosa et al., 2021). At the same time, IT is considered to be an important enabler that contributes to the achievement of competitive advantages with the ASC strategy (Christopher, 2000; DeGroote \& Marx, 2013; Mandal, 2018) and a variety of studies have investigated the role that it plays in driving up agility (Dubey et al., 2019a; Humdan et al., 2020; Sharma et al., 2017).

In this sense, several studies find a positive association between IT and both of these SC strategies (Qrunfleh et al., 2012; Swafford et al., 2008). However, the previous findings suggest that these relationships are expressed in a variety of ways, often in combination with other influential variables; some studies yield contradictory findings when analyzing different types of IT (Ding et al., 2012; Samdantsoodol et al., 2017).

Prior literature reviews exist that have investigated the relationship between IT, SCM, and performance (Zhang et al., 2011), the role of IT in sustainable SCM (Thöni \& Tjoa, 2017), and the role of Industry 4.0 technologies classified according to the Life Cycle of Technology in the specific context of the LSC (Núñez-Merino et al., 2020). On the other hand, it would be necessary to analyze separately the impact that IT has on lean and agile supply chains because both strategies can be applied taking into account the decoupling point. Thus, the supply chain would be lean before the decoupling point and agile before the decoupling point (Mason-Jones et al., 2000; Naylor et al., 1999). With this idea in mind, this study investigates separately the relationships between IT and each of these supply chain strategies. The purpose is to understand how the way that IT is conceptualized affects its role in Lean and Agile strategies and whether there is a consequential effect on performance. Our study specifically seeks to identify consensus and opinions, improve conceptual clarity, and encourage the practical exploitation of synergies between the domains. For this, a Systematic Literature Review (SLR) is carried out (Denyer \& Tranfield, 2009). The SLR method allows to locate, select, evaluate, and synthesize information on a particular subject (Denyer \& Tranfield, 2009). These steps are carried out following protocols that can be verified and replicated by other researchers (Denyer \& Tranfield, 2009; Thomé et al., 2016). Furthermore, SLR is argued to be more rigorous and transparent and, consequently, more robust than other unstructured literature reviews (Tranfield et al., 2003). Moreover, SLR is a versatile approach adopted in recent studies on different research topics published in high-quality scientific journals, for example purchasing and supply chain management (Chiksand et al., 2012) and the lean field (Danese et al., 2018). In this sense, SLR is considered to be an appropriate method for this 
study as it helps to identify and select the existing and relevant body of knowledge on IT and LSC/ASC, thus providing a comprehensive overview of the literature by answering research questions and indicating future research directions.

The review focuses on survey-based research, following the line of earlier works (Rungtusanatham et al., 2003; Zhang et al., 2011). The survey-based research aims to test theoretical models and the goal is explanatory, looking for correlation and/or causality relationships between variables, whereas qualitative methodology is preferably used for exploratory or descriptive purposes. Therefore, putting the focus on survey-based research will allow us to contrast those relationships previously studied in the literature.

An overview of the different relationships studied and of the empirical support that these relationships receive would be very useful for both theory and practice. For theory, it would inform about the relationships that receive the greatest consensus and identify the contradictions found. This would, in turn, enable the identification of the gaps and the research lines that should be pursued in the near future. At the managerial level, the findings would allow managers to understand IT's role in both of the SC strategies and the variables that should be managed to achieve greater responsiveness in the chain through flexibility and/or agility.

The paper proceeds as follows: after this introduction, the second section presents the background. The third section presents the methodology used. In the fourth section, the results of our research are presented. Lastly, the implications and conclusions are presented in the fifth section.

\section{Background}

\subsection{Key issues, conceptualization}

\subsubsection{Lean supply chain (LSC) and agile supply chain (ASC)}

The LSC concept refers to a set of organizations that work together to reduce waste by efficiently pulling, increasing flexibility, decreasing cost, and improving the quality of supply chain activities from the final customer's point-of-view (Lamming, 1996; Moyano-Fuentes et al., 2019, 2021). At the strategic level, LSC focuses on the application and management of Lean principles and practices across the supply chain (Lamming, 1996; Moyano-Fuentes et al., 2021). In this sense, an LSC must be based on close relationships, information needs to be transparent throughout the supply chain, and performance must be monitored (Mor et al., 2019; Paul et al., 2019; Sangwa \& Sangwan, 2018). A fundamental requirement for this is greater coordination and management of physical, information, and financial flows between the various agents involved (Novais et al., 2020). LSC is connected with the responsiveness of the supply chain (Qrunfleh \& Tarafdar, 2013).

On the other hand, ASC can be defined as a set of organizations that focuses on the supply chain's ability to understand and rapidly respond to market changes (Christopher, 2000; Tarafdar \& Qrunfleh, 2017). The literature suggests that an ASC has some specific characteristics, including being market sensitive and having a high level of shared information and connectivity between partners (Dubey et al., 2020; Gligor \& Holcomb, 2012). ASC strategy employs make-to-order provisions, not committing to products until demand becomes known, and using rapid replenishment and postponed fulfillment (Goldsby et al., 2006; Lalmazloumian et al., 2016). ASC focuses on the ability to meet market requirements and requires capacity to be set aside to handle volatile demand (Christopher, 2000; Qrunfleh 
\& Tarafdar, 2014) by increasing service level and shortening lead times (Stewart \& Ivanov, 2019). Furthermore, the use of IT is generally indicated as an enabler for the deployment of this strategy and for supply chain agility to be achieved (Gligor \& Holcomb, 2012). Supply chain agility is the term used for the ability derived from the ASC strategy (Sharma et al., 2017).

Furthermore, some literature, points out that the LSC strategy is appropriate when demand is reasonably predictable and stable and product variety is low (Christopher, 2000; Qi et al., 2011), while the ASC strategy is often adopted when there is a high degree of demand and supply uncertainties (Lee, 2002). Despite their differences, LSC and ASC strategies share a common objective, to meet demand at the lowest total cost (Goldsby et al., 2006), and act in a similar way, developing long-term lines of action to achieve flexibility and/or agility objectives in supply chains (Moyano-Fuentes et al., 2019). Another strategy, the resilient supply chain, designs action plans to recover from major disturbances at specific moments in time (major disturbances may or may not occur) and its action mechanism is different from that of LSC and ASC (Ivanov, 2020; Ponomarov \& Holcomb, 2009). The similarities of the LSC and ASC action mechanisms has fostered an interest in studying the two strategies simultaneously (Ghobakhloo \& Azar, 2018a; Moyano-Fuentes et al., 2019; Qrunfleh \& Tarafdar, 2013). Indeed, the concept of "leagile", which takes the view as the combination of both paradigms, has been promulgated (e.g., Bruce et al., 2004; Mason-Jones et al., 2000; Naylor et al., 1999). Mason-Jones et al. (2000) argue that there are decoupling points within particular SCs that require a Lean approach at one point and an Agile approach at another. The supply chain should be, therefore, lean upstream and agile downstream from the decoupling point in the supply chain (Li et al., 2020; Mason-Jones et al., 2000; Naylor et al., 1999).

\subsubsection{Information technology (IT)}

IT at the company level is defined as a set of tools that enable the transformation of data into useful information and manage it to meet certain business objectives (Boaden \& Lockett, 1991). Thus, IT is applied to various business processes, including processes associated with the Supply Chain (Calatayud et al., 2019). In the IT literature, this broad set of tools (including information systems, communication technologies, and digital technologies) has been conceptualized in different ways. First, IT is interpreted from a static perspective in the literature as a resource that companies can use to achieve their objectives (Powell \& Dent-Micallef, 1997). Ways to identify these resources as static elements include a) considering them as an investment in IT, such as IT infrastructure for example (IT investment), and b) considering the extent of the use of IT resources (IT use) (Devaraj \& Kohli, 2003; Kamble et al., 2020). Second, IT has been conceptualized from a dynamic perspective that focuses on the capabilities developed in companies by operationalizing the resources that IT incorporates (IT capability) (Bharadwaj, 2000; Liu et al., 2013). Therefore, according to the previous literature (Bharadwaj, 2000; Zhang et al., 2011), these three conceptualizations can be interpreted as three consecutive stages of IT employment. In the first stage (IT investment), IT adoption is incipient and has no direct impact on performance. In the second stage (IT use), companies can perceive greater benefits from IT. In the third stage (IT capability), companies develop capabilities and IT has a greater impact on the achievement of strategic objectives (Zhang et al., 2011). In this sense, drawing on the resource-based view (RBV) of the firm, substantial evidence has been found that when IT is considered an isolated resource (IT investment or IT use), it does not, by itself, constitute a competitive advantage as it can easily be mimicked by competitors (Barney, 1991; Powell \& Dent-Micallef, 1997; Yu et al., 
2017). It is when IT resources are used in conjunction with other company resources and capabilities such as human and management resources, that firms develop capabilities that can be generators of sustainable competitive advantage (Dubey et al., 2019a; Yu et al., 2017).

\subsection{IT-LSC and IT-ASC relationships}

There is some convincing empirical evidence in the literature as to the relationships between IT and Lean and Agile supply chain strategies (Mittal et al., 2017; Qrunfleh et al., 2012; Swafford et al., 2008). The results of some surveys show that IT can support the implementation of LSC practices such as Just in Time delivery, Kanban, and pull systems (e.g., Kamble et al., 2020; Khanchanapong et al., 2014). In the same line, surveys on the relationship between IT and ASC also found empirical support for IT's role in underpinning the accomplishment of agile goals. In this sense, some findings suggest that IT can support, for example, the detection of changes in the environment and the continuous collection of information from suppliers and customers (Dubey et al., 2019a; Tarafdar \& Qrunfleh, 2017). Previous findings suggest that IT-LSC/ASC relationships are expressed in a variety of ways (Samdantsoodol et al., 2017; Sharma et al., 2017). Moreover, according to findings in the literature, the relationships between IT and LSC/ASC could be direct, indirect, or complementary. First, the relationship is direct when IT has a direct impact on Lean or Agile supply chains, i.e., these supply chain strategies directly benefit from the application of IT (Boyd et al., 2012; Sangari \& Razmi, 2015). An indirect relationship means that the IT effects on Lean or Agile supply chains are mediated by other variables (Boyd et al., 2012). Finally, the relationship is complementary when the interaction (moderation or joint effect) between IT and LSC or ASC practices results in better (or worse) outcomes, for example, by compensating for (or strengthening) each other's weaknesses (Boyd et al., 2012; Tarafdar \& Qrunfleh, 2017).

Quantitative methods of analysis of information captured through surveys are used to measure the relationships between variables (Rungtusanatham et al., 2003). Survey studies provide theoretical knowledge on how variables are related that is highly generalizable (Karlsson, 2010). However, in general, surveys also have some limitations (Karlsson, 2010). For example, it should be noted that the effectiveness of the method depends on several aspects such as the use of clearly defined concepts (Shah \& Goldstein, 2006). More specifically, some concerns can be highlighted about survey-based research on the IT-LSC/ASC relationship. First, initial scrutiny has found that a long list can be drawn up of seemingly different IT measurements. This concern is similar to the previous findings on the IT-SCM relationship that found different conceptualizations of IT (Zhang et al., 2011). On the other hand, it is not a major concern for LSC/ASC measurements (Gligor \& Holcomb, 2012; Moyano-Fuentes et al., 2019). Second, some studies yield contradictory findings, often IT are measured in combination with other influential variables, without any apparent consensus on these influential variables (Chiarini \& Vagnoni, 2017; Samdantsoodol et al., 2017).

The above concerns have motivated us to dig deeper into the results on the IT-LSC/ASC relationships found in the literature and to offer some directions to improve theory development in this area.

\section{Methodology}

The methodology used in this work consists of a Systematic Literature Review (SLR) (Denyer $\&$ Tranfield, 2009). The review process has been carried out following the five steps proposed 
by Denyer and Tranfield (2009): (i) Formulation of the research question(s); (ii) Identification of studies; (iii) Selection and evaluation of studies; (iv) Analysis and synthesis, and (v) Reporting of results and discussion. In the following, we indicate how these five steps have been carried out in the specific framework of this work.

\subsection{Formulation of the research question(s)}

The first step in an SLR consists of defining the research questions. These must reflect the study's scope and purpose. The study objective is located at the intersection area between the IT concept and both the LSC and ASC concepts. The definitions of the key concepts should be clearly specified (Seuring et al., 2021), therefore, Fig. 1 shows the key concepts and the area in which the identified papers are located.

In relation to these key concepts and since this research aims to clarify the relationships between IT and two supply chain strategies (LSC and ASC) by identifying agreements and disagreements on the research fields, the following question has been defined as a general research question to guide the present study:

RQ (basic research issue): What role does Information Technology play in Lean and Agile supply chain strategies?

In this sense, the first step is to locate the literature on IT-LSC and IT-ASC (RQ1). For this, it is essential to perform the search in relevant scientific databases and define quality criteria to select the studies to be considered in the review. Second, given that different types of relationships - direct, indirect, and complementary - between the key concepts are reported in the literature, it is important to map the developments in the field to understand their integration and its effect on performance (RQ2). Third, according to the previous literature, IT can be conceptualized in different ways, so it would be explanatory to determine how different IT conceptualizations (e.g., IT investment and IT capability) affect the two supply chain strategies (RQ3). Finally, to fulfill the SLR's purpose of encouraging and facilitating subsequent research, the fourth step is to identify unexplored areas and raise questions for future investigation (RQ4).

Therefore, this study addresses the following four specific research questions:

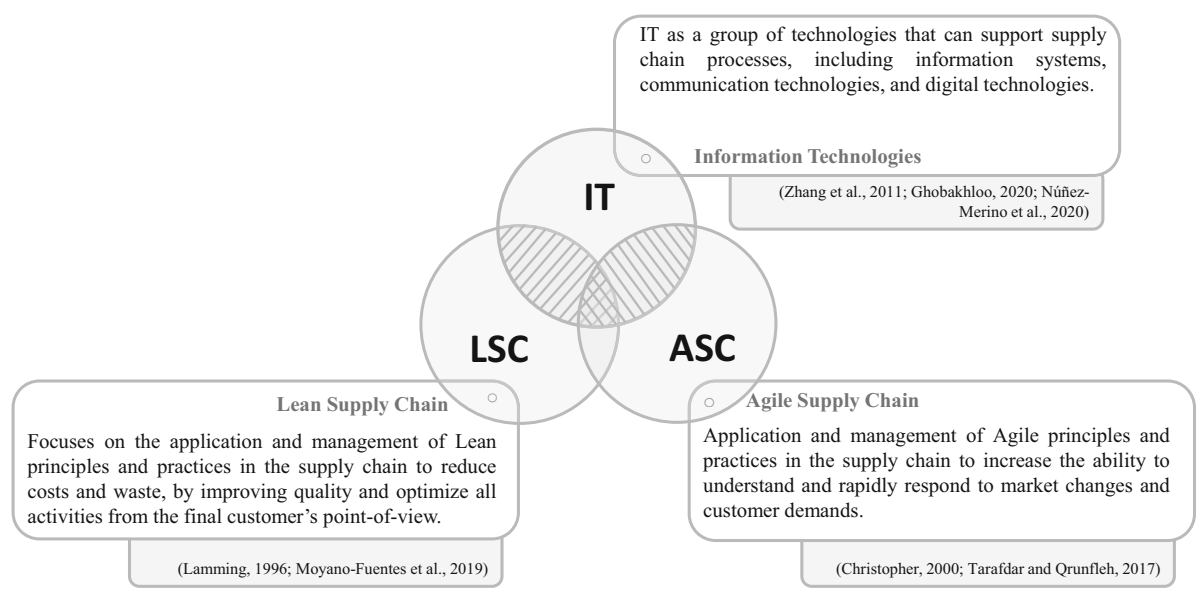

Fig. 1 Key concepts and research objective of the SLR. Source: Prepared by authors 
RQ1: What is the existing survey-based literature on the relationships between IT and the Lean and Agile supply chain strategies and what are their key aspects?

RQ2: What relationships have been observed in the literature between IT and the Lean and Agile supply chain strategies and how have these relationships transferred to performance?

RQ3: What effect does the way that Information Technology is conceptualized have on Lean and Agile supply chain strategies?

RQ4: What gaps and challenges exist for future research in the area of this study?

\subsection{Identification of studies}

In the present case, the most relevant scientific databases in the area have been used for locating the studies, including Web of Science (WOS), Scopus, and EBSCOhost. Two search strings were created to identify the literature in these databases. The first was formed of keywords related to IT and LSC and the second of words related to IT and ASC. An analysis of previous reviews (Núñez-Merino et al., 2020; Pagliosa et al., 2021) and a brainstorming session by the study's authors were performed to define the keywords used. Three sets of keywords were defined for each search, representing IT, Lean, and supply chain in the first case, and IT, Agile, and supply chain in the second. Simple operators were used to combine the keywords and generate the search strings, including truncated characters (e.g., *, "exact phrase") and Boolean operators (e.g., AND, OR). It was also necessary to adapt the search string to each of the databases, as their syntaxes differ. The keywords used are given in Table 1. It was determined that the defined sets of keywords should appear in the following fields: title, abstract or article keywords, depending on the possibilities offered by the different databases.

Table 1 Keywords and search strings

Keywords

(A) LSC (lean OR leanness OR jit OR just-in-time OR "toyota production system") AND ("supply chain*" OR logistic*)

(B) ASC (agile OR agility) AND ("supply chain*" OR logistic*)

(C) IT ("information system*" OR "information technolog*" OR "information and communication* technolog*” OR "digital technolog*” OR ict OR "technological innovation" OR "internet of things" OR iot OR cloud OR web OR e-business OR e-commerce OR "enterprise resource planning" OR erp OR "material* requirement* planning” OR mrp OR "electronic data interchange" OR edi OR "radio-frequency identification" OR rfid OR "business intelligence" OR software OR "artificial intelligence" OR "big data" OR "industry* 4.0" OR e-procurement OR "cyber physical system*” OR blockchain OR "augmented reality" OR "virtual reality" OR "additive manufacturing" OR robotic* OR “3D print*” OR cybersecurity OR "industrial simulation" OR "warehouse management system" OR “transportation management system”)

Search strings 


\section{3 (iii) Selection and evaluation of studies}

Inclusion and exclusion criteria were determined for the selection and evaluation of the works. The first inclusion criterion applied was the publication period of the works. This was limited to 1996-December 2019 for works on IT and LSC and 1999-December 2019 for works on IT and ASC. The starting year for the two searches corresponds to the first publications on the strategies, Lamming (1996) for LSC and Mason-Jones and Towill (1999) and Naylor et al. (1999) for ASC. Apart from this, only works written in English were considered in article, early access article or review format and published in research areas related to the study subject area. Duplicates of articles that were retrieved in the search results for the different databases were also excluded. The reference database used for the results was WOS and all duplicate studies in subsequent searches were removed.

To ensure the quality of the selected studies, the next step was to discard any articles published in journals not indexed in JCR and/or SJR. An analysis was then done of the selected articles' titles, abstracts, and keywords to ensure that they complied with the research questions. Following this, the works were read through in full and those not related to the research issue (false positives) were removed. Other works were discarded that considered Lean or Agile solely from an internal focus, i.e., without considering the SC. The last inclusion criterion was the methodology used in the article. This review has been restricted to survey-based research. The reason for this is that it enables a homogeneous comparison of articles. Also, the purpose of quantitative methodology is to test theoretical models and the goal is explanatory, whereas qualitative methodology is preferably used for exploratory or descriptive purposes. This same criterion has previously been used in other works related to SCM (Rungtusanatham et al., 2003; Zhang et al., 2011). Lastly, both forward and backward searches were performed to guarantee the inclusion of new articles with the snowball effect (Okoli \& Schabram, 2011; Thomé et al., 2016). Three new articles were added during this stage.

The search yielded a total selection of 59 papers, 13 of which address the IT-LSC relationship, 39 articles that analyze the IT-ASC relationship, and 7 that analyze both IT-LSC and IT-ASC relationships.

\section{4 (iv) Analysis and synthesis}

For the content analysis evaluation, information was extracted from every study included in the review and stored. Selected papers were categorized in Mendeley, which is a useful tool for information coding, by tagging each article based on its key concepts, creating notes, and highlighting relevant information. At the same time, a database was created in Excel to code the content of the articles. For this, information was collected on the supply chain strategy adopted (LSC or/and ASC), the purposes, the theories adopted, the main contributions, the variables adopted in each study and their roles (e.g., independent, dependent, mediator, moderator), and the relationships between the key concepts. More specifically, the relationships between IT and both SC strategies have been determined after evaluating the selected articles through an iterative process of identification and revision. As a result, this process identified nine types of relationships between the study's key concepts (see Table 2).

Furthermore, considering the relationships studied and according to the types of interaction between IT and LSC or ASC, respectively, the studies were classified into three approaches: (i) IT-LSC/IT-ASC direct relationship; (ii) IT-LSC/IT-ASC indirect relationship, and (iii) ITLSC/IT-ASC complementary relationship. Subsequently, following the background of this article, we distinguish whether IT is conceptualized as a resource (IT investment or IT use) 
Table 2 Summary of relationships

Relationships

\begin{tabular}{|c|c|c|c|}
\hline A: & Direct relationship between IT and LSC or ASC & IT & LSC/ASC \\
\hline B: & $\begin{array}{l}\text { Relationship between IT and another factor in the presence of LSC or } \\
\text { ASC }\end{array}$ & IT & $\begin{array}{l}\text { Another } \\
\text { factor }\end{array}$ \\
\hline \multirow[t]{2}{*}{ C: } & $\begin{array}{l}\text { Relationship between another factor and LSC or ASC in the presence } \\
\text { of IT }\end{array}$ & $\begin{array}{l}\text { Another } \\
\text { factor }\end{array}$ & LSC/ASC \\
\hline & & & \\
\hline \multirow[t]{2}{*}{ D: } & IT as a moderator between LSC or ASC and performance & LSC/ASC & Performance \\
\hline & & \multicolumn{2}{|c|}{ LSC/ASC } \\
\hline E: & LSC or ASC as a moderator between IT and performance & IT & Performance \\
\hline F: & $\begin{array}{l}\text { Direct relationship between LSC or ASC and performance in the } \\
\text { presence of IT }\end{array}$ & LSC/ASC & Performance \\
\hline \multirow[t]{2}{*}{ G: } & Direct relationship between IT and performance in the presence of & IT & Performance \\
\hline & & & \\
\hline \multirow[t]{2}{*}{ H: } & IT as a moderator between another factor and LSC or ASC & $\begin{array}{l}\text { Another } \\
\text { factor }\end{array}$ & LSC/ASC \\
\hline & & IT & Performance \\
\hline I: & Joint effect of IT and LSC or ASC on performance & LSC/ASC & \\
\hline
\end{tabular}

or capability (IT capability). Finally, according to the IT's level of analysis, we determine whether it is measured as an aggregate (generic concept) or a specific kind of technology.

These pre-defined coding schemes, which are based on the theoretical background and the clear definition of constructs allow the involvement of the different researchers in this process, help to avoid common biases in the SLR process (Durach et al., 2017), and shed light on the data analysis process and how theory is employed (Seuring et al., 2021). Therefore, as recommended by good practice in content analysis (Seuring \& Gold, 2012), a two-step categorization process has been followed. First, the basic categorization framework has been established based on existing theory, and second, some of the categories have subsequently been refined during the coding process. Furthermore, discussions among the research team have allowed to reach a consensus and consolidate the results, which in turn improves the internal validity of the findings (Seuring \& Gold, 2012).

\section{5 (v) Reporting of results and discussion}

The results of this step are presented in the following section. Figure 2 illustrates the methodological procedure followed in this study and described in a flow diagram in this section. The diagram shows the flow of information through the different SLR phases and gives the number of records identified, included and excluded and the reasons for their exclusion, as recommended by best practice for conducting an SLR in operations management (Thomé et al., 2016), in SCM (Durach et al., 2017), and in Information Systems research (Okoli \& Schabram, 2011). 


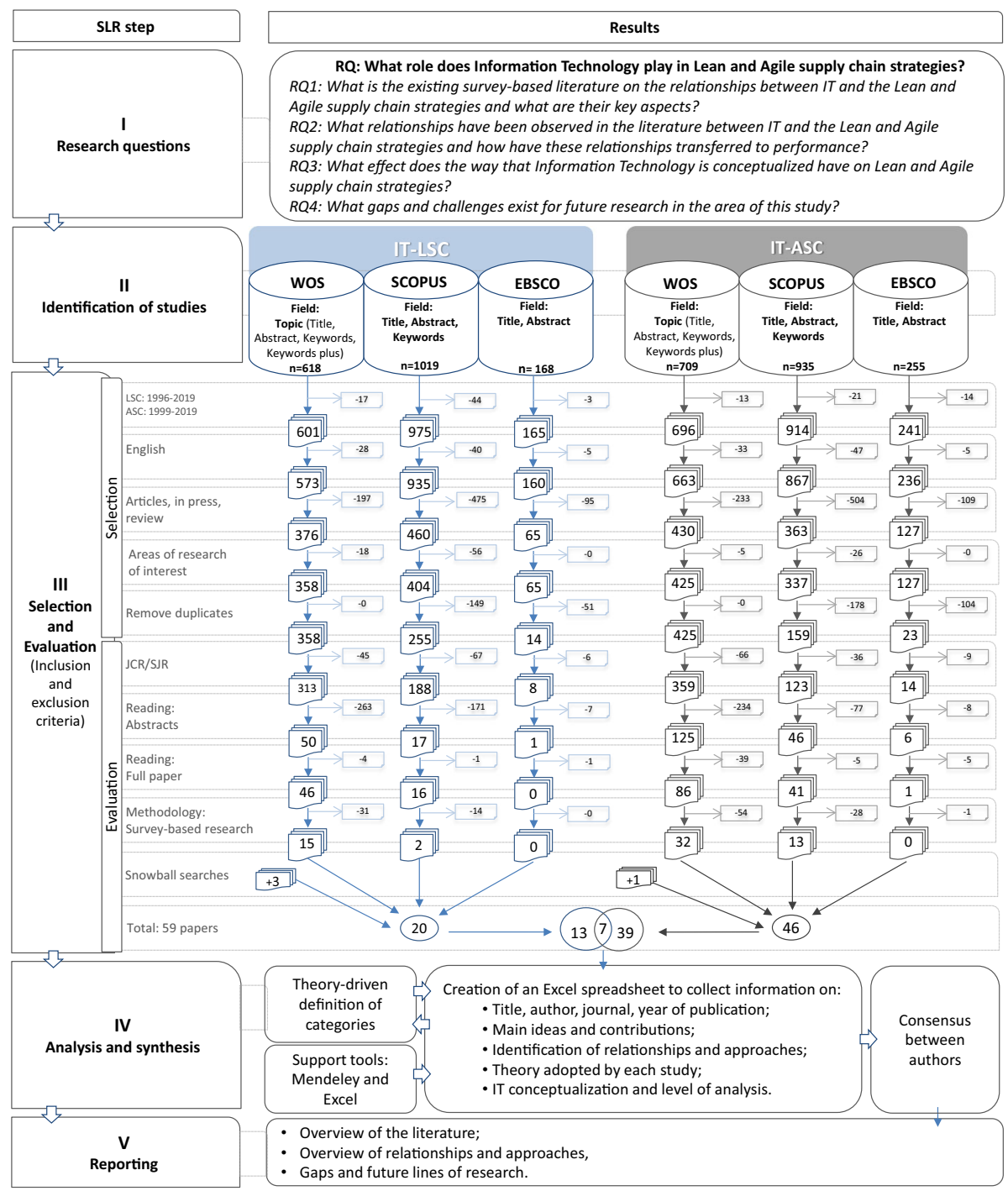

Fig. 2 Summary of the Systematic Literature Review. Source: Prepared by authors

\section{Results}

\subsection{Descriptive analysis}

First, the selected body of literature was classified by the addressed supply chain strategy, LSC, or ASC (see Table 3). Note that 7 papers address both SC strategies. The results of these 7 articles will be considered taking into account the role of IT in each of the strategies independently.

The set of selected documents was published over 19 years, between 2001 and 2019. In the specific case of the literature on IT-ASC, over $70 \%$ of the papers are from the last 5 years, 
Table 3 Papers by SC strategy

\begin{tabular}{ll}
\hline Scope & Papers \\
\hline IT-LSC & Ahmad and Schroeder (2001); Bayraktar et al. (2009); Bayraktar et al. (2010); \\
& Ghobakhloo and Hong (2014); Ghobakhloo et al. (2018); Hong et al. (2010); \\
& Kamble et al. (2020)*; Karakadilar and Hicks (2015); Khanchanapong et al. (2014); \\
& Kou et al. (2018); So and Sun (2010); So and Sun (2011); Zelbst et al. (2014) \\
& Almahamid and Hourani (2015); Al-Nimer (2019); Bargshady et al. (2016); Bi et al. \\
& (2013); Brusset (2016); Chen (2019); DeGroote and Marx (2013); Dehgani and \\
& Navimipour (2019); Ding et al. (2012); Dubey et al. (2019a); García-Alcaraz et al. \\
& (2017); García-Alcaraz et al. (2019); Hwang and Rho (2016); Kabra and Ramesh \\
& (2016); Kumar et al. (2017); Liu et al. (2013); Liu et al. (2018); Mandal (2018); \\
& Mandal (2019a); Mandal (2019b); Motadel et al. (2011); Oh et al. (2019); \\
& Panichayakorn and Jermsittiparsert (2019); Paulraj and Chen (2007); Pool et al. \\
& (2018); Rahimi et al. (2019); Samdantsoodol et al. (2017); Samizadeh et al. (2019); \\
& Sangari and Razmi (2015); Schniederjans et al. (2016); Sheel and Nath (2019); \\
& Swafford et al. (2008); Tarafdar and Qrunfleh (2017); Vagnoni and Khoddami \\
& (2016); Vickery et al. (2010); Wamba and Akter (2019); Wamba et al. (2020); \\
& Yang (2014); Yusuf et al. (2004) \\
& Chiarini and Vagnoni (2017); Ghobakhloo and Azar (2018a); Ghobakhloo and Azar \\
& (2018b); Gorane and Kant (2017); Qrunfleh and Tarafdar (2014); Qrunfleh et al. \\
& (2012); Shahin et al. (2016) \\
\hline IT-LSC/ASC &
\end{tabular}

*In-press version published in 2019

whereas in the literature on IT-LSC, $45 \%$ of the papers were published in the last 5 years. Interestingly, since 2015, IT-ASC has been explored more than IT-LSC, especially in 2019. Explanations for this may be that emergent IT such as Cloud Computing and Big Data and the development of Industry 4.0 could be having a greater influence on ASC strategy.

Figure 3 is a graph of the number of studies published per year and the cumulative frequency of the two major research topics considered.

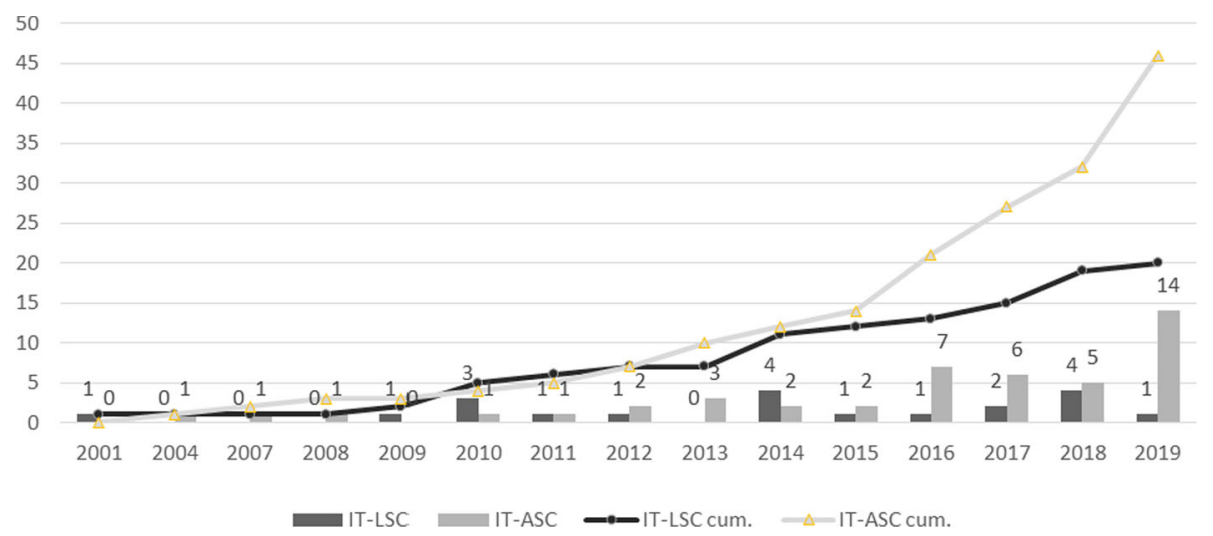

Fig. 3 Distribution of papers by year and cumulative frequency. Source: Prepared by authors 


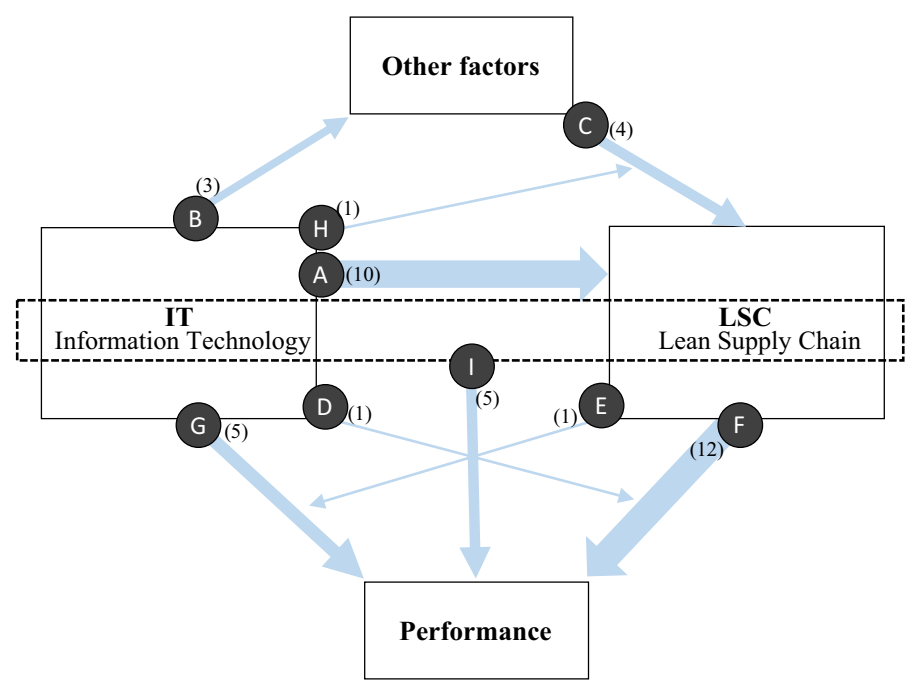

Fig. 4 Summary of the relationships in the IT-LSC literature. Source: Prepared by authors

\subsection{Overview of relationships in the IT-LSC survey-based research}

Nine types of relationships were identified in the analysis of the 20 selected articles. Articles may have analyzed one or more relationships. Figure 4 represents the distribution of papers according to the type of relationship. The thickness of the line is proportional to the number of papers that address each relationship with the number also given in parentheses. Table 4 also shows the distribution of the papers over these different relationships and whether these relationships are positive, negative, or non-significant.

In short (see Table 4), considering the positive and significant relationships, on the one hand, the main results show that IT had a direct effect on LSC in $45 \%$ of the 20 papers and that LSC had a direct effect on performance in $60 \%$ of the 20 papers. On the other hand, some relationships were less explored, for example, the moderating role of IT was addressed in only $10 \%$ of the papers.

\subsection{Overview of relationships in the IT-ASC survey-based research}

Seven types of relationships were found in this literature. Following the same criteria as in Fig. 4 and Table 4, Fig. 5, and Table 5 respectively show the distribution of papers according to each relationship.

Considering the positive relationships (see Table 5), the main results indicate that IT had a direct effect on ASC in almost $70 \%$ of the 46 papers and that ASC had a direct effect on performance in $56 \%$ of the 46 papers. Some relationships require a deeper understanding, such as the moderating role of IT, which was studied in $11 \%$ of the papers. 
Table 4 Relationships in the IT-LSC survey-based research

\begin{tabular}{|c|c|c|c|c|c|c|c|c|c|}
\hline \multirow{2}{*}{$\begin{array}{l}\text { Literature on IT-LSC } \\
\text { Author }\end{array}$} & \multicolumn{9}{|c|}{ Relationships } \\
\hline & A & $\mathrm{B}$ & $\mathrm{C}$ & $\mathrm{D}$ & E & $\mathrm{F}$ & $\mathrm{G}$ & $\mathrm{H}$ & I \\
\hline Ahmad and Schroederc (2001) & & & & & & & & & + \\
\hline Bayraktar et al. (2009) & & & & & & & & & + \\
\hline Bayraktar et al. (2010) & & & & & & & & & + \\
\hline Chiarini and Vagnoni (2017) & - & & & & & & & & \\
\hline Ghobakhloo and Azar (2018a) & + & & & & & + & & & \\
\hline Ghobakhloo and Azar (2018b) & + & & & & & + & ఈ & & \\
\hline Ghobakhloo and Hong (2014) & + & & & & & + & & & \\
\hline Ghobakhloo et al. (2018) & + & & & & & & & & \\
\hline Gorane and Kant (2017) & & + & + & & & + & & & \\
\hline Hong et al. (2010)* & & & & & & + & & & +1 \\
\hline Kamble et al. (2020) & + & & & & & + & + & & \\
\hline Karakadilar and Hicks (2015) & & & & & ) & + & + & & \\
\hline Khanchanapong et al. (2014) & & & & & & + & + & & + \\
\hline Kou et al. (2018) & + & & & & & + & & & \\
\hline Qrunfleh and Tarafdar (2014) & & & & + & & + & & & \\
\hline Qrunfleh et al. (2012) & & & + & & & & & + & \\
\hline Shahin et al. (2016) & + & & & & & + & + & & \\
\hline So and Sun (2010) & + & & & & & & & & \\
\hline So and Sun (2011) & & + & + & & & & & & \\
\hline Zelbst et al. (2014)* & +10 & + & + & & & + & & & \\
\hline Total & 10 & 03 & 04 & 01 & 01 & 12 & 05 & 01 & 05 \\
\hline
\end{tabular}

(+) Positive; (-) Negative; () Non-significant

*Articles that have analyzed more than one type of technology and have found different results depending on the technology type

\subsection{IT-LSC approaches}

The following analyzes each of the three approaches (direct, indirect and, complementary relationship) in detail.

(i) IT-LSC direct relationship The direct impact of IT on LSC was analyzed in 10 studies. Of these, some studies (Ghobakhloo et al., 2018; Ghobakhloo \& Azar, 2018a, 2018b; Ghobakhloo \& Hong, 2014; Kamble et al., 2020; So \& Sun, 2010) concluded that IT specifically contributes to improving the implementation of Lean Management practices. IT use can also directly and positively affect the improvement of Just-In-Time (JIT) practices (Zelbst et al., 2014) and the launch of products from a Lean perspective (Kou et al., 2018). However, IT does not significantly enhance Total Quality Management (TQM) practices (Zelbst et al., 2014) and a negative relationship between IT and LSC was found in one case (Chiarini \& Vagnoni, 2017). In this case, the paper's results indicate that Enterprise Resource Planning (ERP) does not provide the flexibility required to adopt LSC practices (Chiarini \& Vagnoni, 2017). Further, as Lean practices help supply chains decrease non-value-added activities to reduce production costs, it is associated 


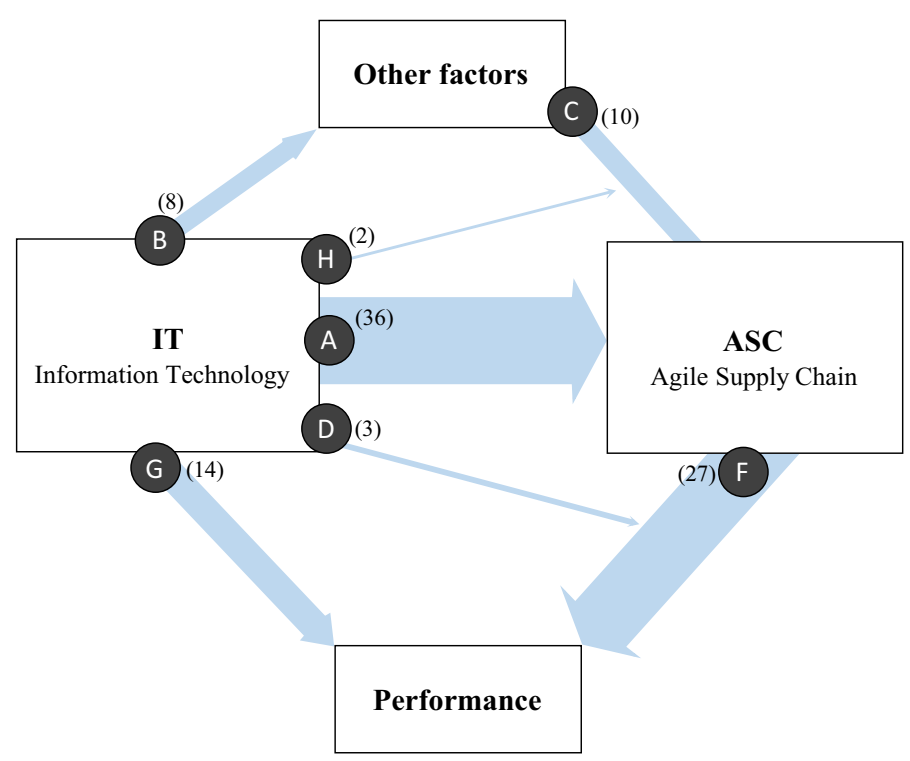

Fig. 5 Summary of the relationships in the IT-ASC literature. Source: Prepared by authors

with improvements in firm or supply chain performance (Ghobakhloo \& Azar, 2018b; Ghobakhloo \& Hong, 2014; Kou et al., 2018; Zelbst et al., 2014).

This approach was tested using three different models (see Fig. 6).

(ii) IT-LSC indirect relationship. The review has found that only 3 papers have considered the IT-LSC indirect relationship. This approach assumes that the relationship between IT and LSC is mediated by other factors, so the impact of IT on LSC is not direct. There is no consensus among researchers on mediating factors. These factors are different in each of the document: the relative advantage of Lean (So \& Sun, 2011), informationsharing (Zelbst et al., 2014), and SC integration (Gorane \& Kant, 2017). This approach was tested using two models (see Fig. 7).

(iii) IT-LSC complementary relationship. This approach assumes that firms can gain additional improvements when IT and LSC practices are used in conjunction, i.e., focusing exclusively on IT or LSC does not provide the best results. This approach is tested with four models in 8 papers (see Fig. 8). The first model (3A) considers an IT-LSC joint relationship that has been an object of interest in the literature (5 papers), whereas the other models (3B, 3C, and 3D) focus on the moderating effects of IT or LSC, which have been tested to an extremely limited extent ( 3 papers).

\subsection{IT-ASC approaches}

Each of the three approaches are analyzed in detail below.

(i) IT-ASC direct relationship. This approach assumes that IT and ASC strategy are directly related (36 papers). The majority of the papers with this approach $(n=30)$ found that IT use has a positive direct effect on ASC (e.g., Mandal, 2018; Wamba \& Akter, 2019). These findings indicate that IT has a direct effect on ASC as it increases the ability to 
Table 5 Relationships in the IT-ASC survey-based research

\begin{tabular}{|c|c|c|c|c|c|c|c|c|c|}
\hline \multirow{2}{*}{$\begin{array}{l}\text { Literature on IT-ASC } \\
\text { Author }\end{array}$} & \multicolumn{9}{|c|}{ Relationships } \\
\hline & A & $\mathrm{B}$ & $\mathrm{C}$ & $\mathrm{D}$ & $\mathrm{E}$ & $\mathrm{F}$ & $\mathrm{G}$ & $\mathrm{H}$ & I \\
\hline $\begin{array}{l}\text { Almahamid and } \\
\text { Hourani (2015)* }\end{array}$ & l+ & + & + & & & & & & \\
\hline Al-Nimer (2019) & + & & & & & + & + & & \\
\hline $\begin{array}{l}\text { Bargshady et al. } \\
\text { (2016) }\end{array}$ & + & & & & & & & & \\
\hline Bi et al. (2013) & & + & + & & & & & & \\
\hline Brusset $(2016)^{*}$ & l+ & & & & & & & & \\
\hline Chen (2019) & + & & & & & + & & & \\
\hline $\begin{array}{l}\text { Chiarini and Vagnoni } \\
\text { (2017) }\end{array}$ & - & & & & & & & & \\
\hline $\begin{array}{l}\text { DeGroote and Marx } \\
\text { (2013) }\end{array}$ & + & & & & & + & & & \\
\hline $\begin{array}{l}\text { Dehgani and } \\
\text { Navimipour (2019) }\end{array}$ & + & & & & & & & & \\
\hline Ding et al. (2012) & & & + & & & & & - & \\
\hline Dubey et al. (2019a) & + & & & & & + & + & & \\
\hline $\begin{array}{l}\text { García-Alcaraz et al. } \\
\text { (2017) }\end{array}$ & + & & & & & + & + & & \\
\hline $\begin{array}{l}\text { García-Alcaraz et al. } \\
\text { (2019) }\end{array}$ & + & & & & & + & + & & \\
\hline $\begin{array}{l}\text { Ghobakhloo and Azar } \\
\text { (2018a) }\end{array}$ & + & & & & & + & & & \\
\hline $\begin{array}{l}\text { Ghobakhloo and Azar } \\
\text { (2018b) }\end{array}$ & + & & & & & + & ब & & \\
\hline $\begin{array}{l}\text { Gorane and Kant } \\
\text { (2017) }\end{array}$ & & + & + & & & & & & \\
\hline $\begin{array}{l}\text { Hwang and Rho } \\
\text { (2016) }\end{array}$ & + & & & & & + & & & \\
\hline $\begin{array}{l}\text { Kabra and Ramesh } \\
\text { (2016) }\end{array}$ & + & & & & & + & + & & \\
\hline Kumar et al. (2017) & + & & & & & + & + & & \\
\hline Liu et al. (2013) & ) & + & + & & & + & & & \\
\hline Liu et al. (2018) & + & & & & & & & & \\
\hline Mandal (2018) & + & & & & & & & & \\
\hline Mandal (2019a) & + & & & & & & & & \\
\hline Mandal (2019b) & + & & & & & & & & \\
\hline Motadel et al. (2011) & + & & & & & & & & \\
\hline Oh et al. (2019) & & & & - & & + & & & \\
\hline
\end{tabular}


Table 5 (continued)

\begin{tabular}{|c|c|c|c|c|c|c|c|c|c|}
\hline \multirow{2}{*}{$\begin{array}{l}\text { Literature on IT-ASC } \\
\text { Author }\end{array}$} & \multicolumn{9}{|c|}{ Relationships } \\
\hline & $\mathrm{A}$ & $\mathrm{B}$ & $\mathrm{C}$ & $\mathrm{D}$ & $\mathrm{E}$ & $\mathrm{F}$ & G & $\mathrm{H}$ & I \\
\hline $\begin{array}{l}\text { Panichayakorn and } \\
\text { Jermsittiparsert } \\
\text { (2019) }\end{array}$ & + & & & & & + & + & & \\
\hline $\begin{array}{l}\text { Paulraj and Chen } \\
\text { (2007) }\end{array}$ & & + & + & & & & & & \\
\hline Pool et al. (2018) & + & & & & & & & & \\
\hline $\begin{array}{l}\text { Qrunfleh and Tarafdar } \\
\text { (2014) }\end{array}$ & & & & + & & + & & & \\
\hline Qrunfleh et al. (2012) & & & + & & & & & i & \\
\hline Rahimi et al. (2019) & + & & & & & & & & \\
\hline $\begin{array}{l}\text { Samdantsoodol et al. } \\
\text { (2017) }\end{array}$ & - & + & + & & & + & & & \\
\hline $\begin{array}{l}\text { Samizadeh et al. } \\
\text { (2019) }\end{array}$ & + & & & & & + & ओ & & \\
\hline $\begin{array}{l}\text { Sangari and Razmi } \\
\text { (2015) }\end{array}$ & + & & & & & + & & & \\
\hline $\begin{array}{l}\text { Schniederjans et al. } \\
\text { (2016) }\end{array}$ & & + & + & & & & & & \\
\hline Shahin et al. (2016) & + & & & & & + & + & & \\
\hline Shell and Nath (2019) & + & & & & & + & & & \\
\hline Swafford et al. (2008) & & + & + & & & + & & & \\
\hline $\begin{array}{l}\text { Tarafdar and Qrunfleh } \\
\text { (2017) }\end{array}$ & & & & + & & + & & & \\
\hline $\begin{array}{l}\text { Vagnoni and } \\
\text { Khoddami (2016) }\end{array}$ & + & & & & & + & ] & & \\
\hline Vickery et al. (2010) & ) & & & & & + & ) & & \\
\hline $\begin{array}{l}\text { Wamba and Akter } \\
\text { (2019) }\end{array}$ & + & & & & & + & + & & \\
\hline Wamba et al. (2020) & + & & & & & + & + & & \\
\hline Yang (2014) & + & & & & & ) & & & \\
\hline Yusuf et al. (2004) & + & & & & & & & & \\
\hline Total & 36 & 08 & 10 & 03 & 0 & 27 & 14 & 02 & 0 \\
\hline
\end{tabular}

(+) Positive; (-) Negative; () Non-significant *Articles that have analyzed more than one type of technology and have found different results depending on the technology type

Model 1A (3 papers)

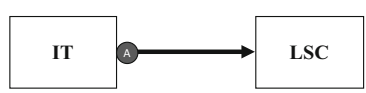

Model 1B (4 papers)

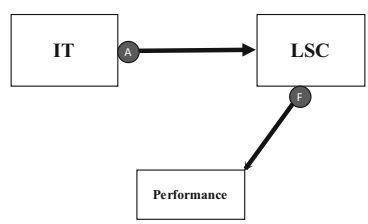

Model 1C (3 papers)

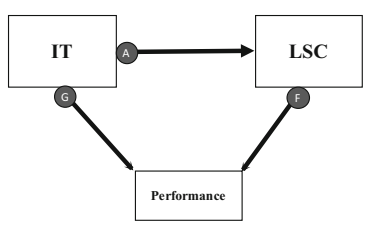

Fig. 6 IT-LSC direct relationship $(\mathrm{n}=10)$ : Models. Source: Prepared by authors 


\section{Model 2A (1 paper)}

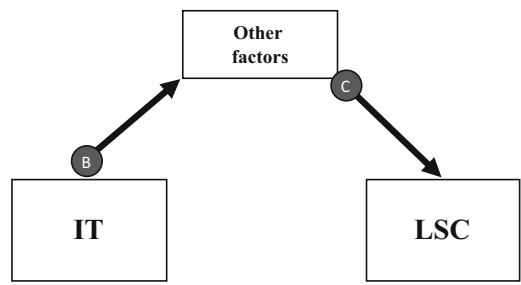

Model 2B (2 papers)

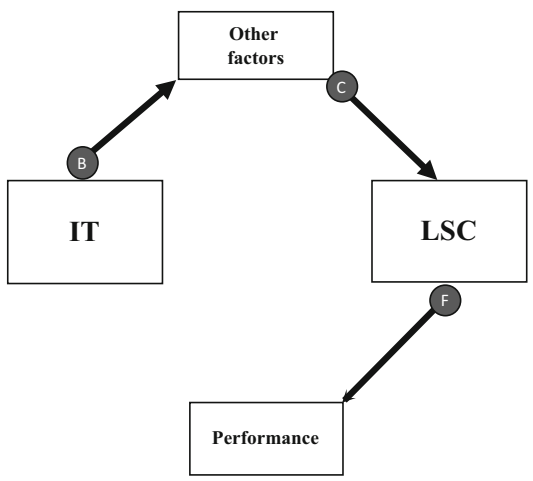

Fig. 7 IT-LSC indirect relationship $(\mathrm{n}=3)$ : Models. Source: Prepared by authors

Model 3A (5 papers)

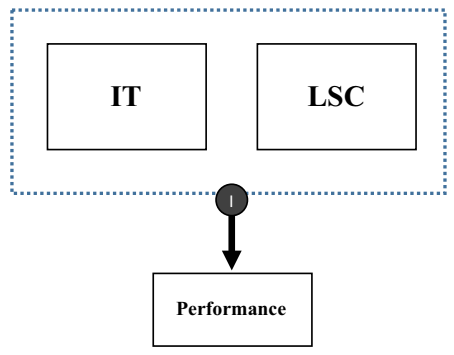

Model 3C (1 paper)

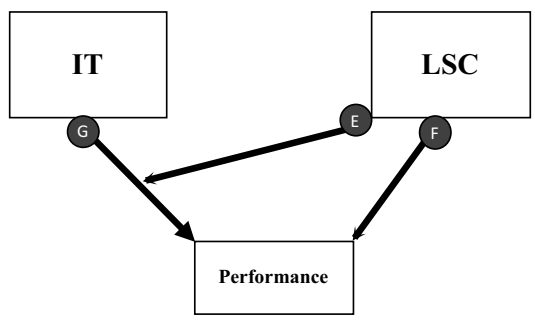

Model 3B (1 paper)

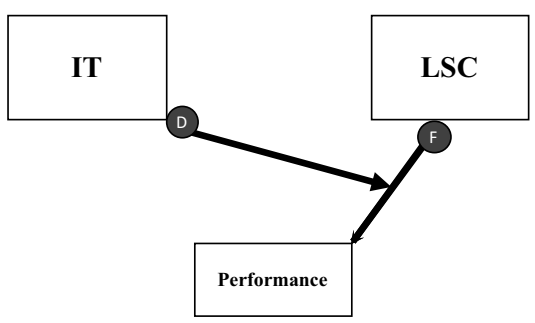

Model 3D (1 paper)

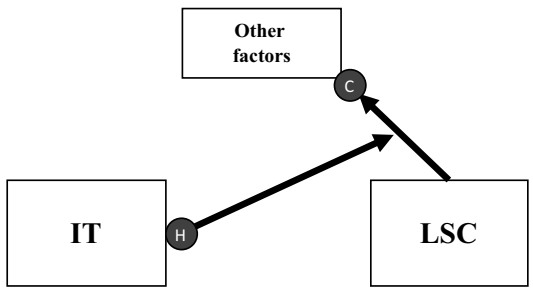

Fig. 8 IT-LSC complementary relationship $(\mathrm{n}=8)$ : Models. Source: Prepared by authors

rapidly detect market changes by facilitating the obtention of information in real-time and supporting the exchange of information between chain partners. IT use also increases the ability to respond to these market changes through agile joint decision-making. In this sense, some studies assume that IT impacts on ASC, which in turn results in greater customer satisfaction and increased company revenue and, consequently, better firm or supply chain performance, i.e., they indicate the existence of a mediating effect of ASC between IT and performance (e.g., DeGroote \& Marx, 2013; Sheel \& Nath, 2019). It has also been found that in some specific cases the direct relationship between IT and 
Model 1A (13 papers)

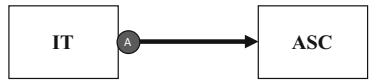

Model 1B (9 papers)

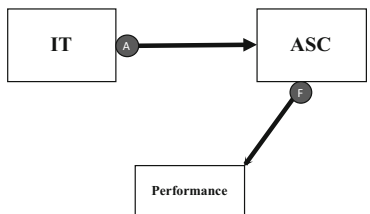

Model 1C (14 papers)

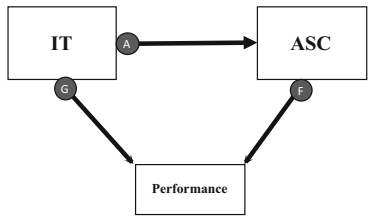

Fig. 9 IT-ASC direct relationship $(\mathrm{n}=36)$ : Models. Source: Prepared by authors

ASC depends on the purpose of IT use or the specific type of IT (Almahamid \& Hourani, 2015; Brusset, 2016).

The IT-ASC direct relationship has been tested using three models (see Fig. 9).

(ii) IT-ASC indirect relationship. This approach implies the existence of a mediating factor in the effect of IT on ASC. The mediating factors used were: collaboration between commercial partners (Almahamid \& Hourani, 2015; Schniederjans et al., 2016), SC integration (Gorane \& Kant, 2017; Paulraj \& Chen, 2007), SC capability (a complex variable that includes SC integration, information, and SC coordination) (Bi et al., 2013), virtual enterprises (Samdantsoodol et al., 2017), absorptive capacity (Liu et al., 2013), and SC flexibility (Swafford et al., 2008). In general, these factors are related to coordination processes across the SC. Therefore, in some cases, to achieve agility, IT first must be complemented with some other supply chain processes in order to later impact ASC and boost firm performance (Liu et al., 2013; Samdantsoodol et al., 2017; Swafford et al., 2008). In other words, if there are any issues with the supply chain, IT does not turn it into an ASC but requires that any problems be solved first. This approach has received less attention in the literature and was tested in 8 studies, with two models (see Fig. 10).

(iii) IT-ASC complementary relationship. This approach assumes that firms can achieve better outcomes when IT and ASC practices are used in conjunction. This approach has been tested in fewer papers $(n=5)$ and the results are positive in only two of these. Two models with moderating relationships were identified (see Fig. 11). In this sense, the results of this approach demonstrate the existence of a lack of agreement on the moderating role of IT.

\subsection{How IT affects lean and agile supply chain}

Table 6 summarizes the approaches to the relationship between IT and each of the SC strategies and considers how IT is conceptualized and measured in the selected papers. Additionally, Table 6 indicates whether the papers are supported by consolidated theories.

IT-LSC As Table 6 shows, most papers (14) conceptualize IT as a resource (IT use), four papers conceptualize IT as a capability, and two papers consider IT as both a possible resource (an IT investment) and a possible IT capability. Table 6 also shows that half of the papers measure IT in aggregate terms (as a generic concept), and the other half, as a specific type of technology (e-business technologies, Radio Frequency Identification-RFID, Advanced Manufacturing Technologies-AMT, ERP). Further, only ten papers are grounded in consolidated theories. The most-used theory is RBV (Barney, 1991), which is widely used in the literature to study the "IT productivity paradox". 
Model 2A (5 papers)

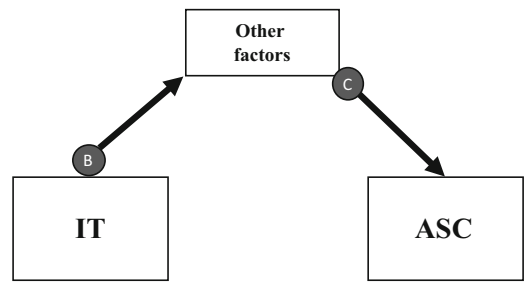

Model 2B (3 papers)

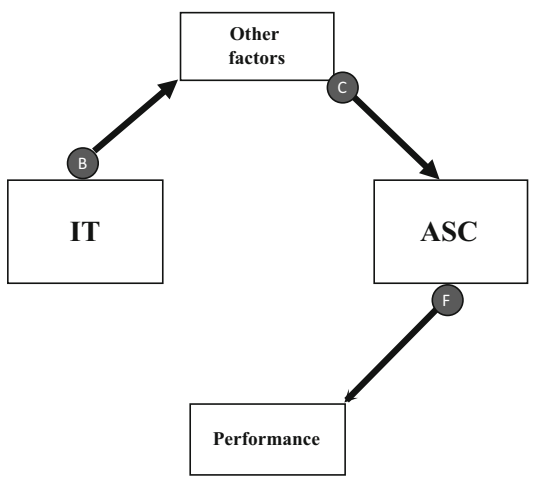

Fig. 10 IT-ASC indirect relationship $(\mathrm{n}=8)$ : Models. Source: Prepared by authors

Model 3B (3 papers)

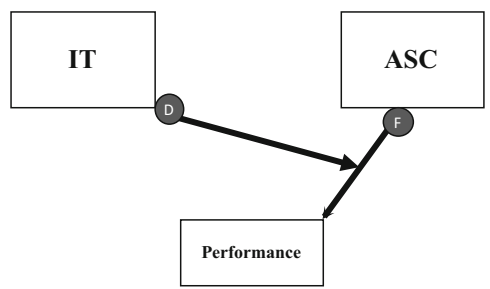

Model 3D (2 papers)

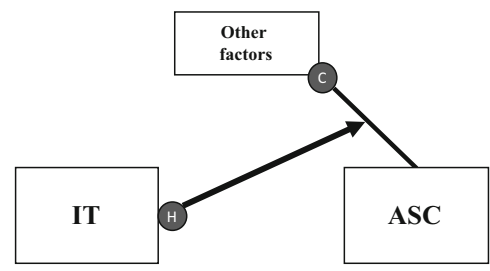

Fig. 11 IT-ASC complementary relationship $(\mathrm{n}=5)$ : Models. Source: Prepared by authors

Our analysis of how the way that IT is conceptualized and measured can affect LSC found that when IT is conceived as a resource, it can positively impact LSC, regardless of whether a general or specific technology approach is adopted. This impact mainly occurs directly but the complementary relationship between IT and LSC and its positive effects on performance have also been confirmed in some studies. However, only the results of the impact of ERP use on LSC (2 papers) show conflicting results (negative or non-significant). Further, when IT is considered as a capability, we have found mostly direct effects (either as an aggregate or as a specific type of IT). The IT efficiency capability, i.e., the support that IT gives for the efficient coordination of inventory and production between partners, is an important feature for achieving LSC strategy goals. However, similar results are found in most papers, despite the IT in question having different characteristics.

IT-ASC According to the evidence in Table 6, most papers (26) conceptualize IT as a capability, nineteen papers conceptualize IT as a resource (IT use), and one paper recognizes IT as both a possible resource (an IT investment) and a possible capability. Table 6 also shows that twenty-eight papers measure IT as an aggregate (as a general concept), and the others (18), as a specific type of technology (e-business technologies, RFID, AMT, ERP, Cloud Computing, Big Data, Business Intelligence, Blockchain). Further, twenty-six papers are grounded in consolidated theories. The most used theories are RBV (14 papers) and its extension, Dynamic Capabilities (Teece, 2007) (12 papers). 
Table 6 IT-LSC/IT-ASC approaches, IT features, and theories

\begin{tabular}{|c|c|c|c|c|c|c|}
\hline \multirow[t]{2}{*}{ Strategy } & \multirow[t]{2}{*}{ Papers } & \multirow[t]{2}{*}{ Approach } & \multirow[t]{2}{*}{ Conceptualization } & \multicolumn{2}{|c|}{ Measurement } & \multirow[t]{2}{*}{ Theory } \\
\hline & & & & Aggregate & Specific IT & \\
\hline LSC & $\begin{array}{l}\text { Ahmad and } \\
\text { Schroederc } \\
(2001)\end{array}$ & $\mathrm{C}$ & RE.U & & E-BUS & \\
\hline LSC & $\begin{array}{l}\text { Bayraktar et al. } \\
\text { (2009) }\end{array}$ & $\mathrm{C}$ & RE.U & AGGRE & & \\
\hline $\mathrm{LSC}$ & $\begin{array}{l}\text { Bayraktar et al. } \\
\quad(2010)\end{array}$ & $\mathrm{C}$ & RE.U & AGGRE & & \\
\hline LSC* & $\begin{array}{l}\text { Chiarini and } \\
\text { Vagnoni } \\
(2017)\end{array}$ & D- & RE.U & & ERP & \\
\hline LSC & $\begin{array}{c}\text { Ghobakhloo and } \\
\text { Azar (2018a) }\end{array}$ & $\mathrm{D}$ & RE.U & & AMT & \\
\hline $\mathrm{LSC}^{*}$ & $\begin{array}{c}\text { Ghobakhloo and } \\
\text { Azar (2018b) }\end{array}$ & $\mathrm{D}$ & RE.I/CAP & AGGRE & & $\begin{array}{l}\text { RBV/ } \\
\text { Tcomp }\end{array}$ \\
\hline LSC & $\begin{array}{c}\text { Ghobakhloo and } \\
\text { Hong (2014) }\end{array}$ & $\mathrm{D}$ & RE.I/CAP & & AMT & $\mathrm{RBV}$ \\
\hline LSC & $\begin{array}{l}\text { Ghobakhloo } \\
\text { et al. (2018) }\end{array}$ & $\mathrm{D}$ & CAP & AGGRE & & RBV \\
\hline LSC* & $\begin{array}{l}\text { Gorane and } \\
\text { Kant (2017) }\end{array}$ & I & RE.U & AGGRE & & \\
\hline LSC & $\begin{array}{l}\text { Hong et al. } \\
\text { (2010) }\end{array}$ & $\mathrm{C} / \mathrm{C}^{0}$ & RE.U & & E-BUS/ERP & ValueCT \\
\hline LSC & $\begin{array}{l}\text { Kamble et al. } \\
\text { (2020) }\end{array}$ & $\mathrm{D}$ & RE.U & AGGRE & & \\
\hline LSC & $\begin{array}{c}\text { Karakadilar and } \\
\text { Hicks (2015) }\end{array}$ & $\mathrm{C}$ & RE.U & AGGRE & & \\
\hline LSC & $\begin{array}{c}\text { Khanchanapong } \\
\text { et al. (2014) }\end{array}$ & $\mathrm{C}$ & RE.U & & AMT & $\mathrm{RBV}$ \\
\hline LSC & Kou et al. (2018) & $\mathrm{D}$ & CAP & AGGRE & & RBV \\
\hline LSC* & $\begin{array}{l}\text { Qrunfleh and } \\
\text { Tarafdar } \\
(2014)\end{array}$ & $\mathrm{C}$ & CAP & AGGRE & & IPT \\
\hline $\mathrm{LSC}^{*}$ & $\begin{array}{l}\text { Qrunfleh et al. } \\
\text { (2012) }\end{array}$ & $\mathrm{C}$ & CAP & AGGRE & & $\mathrm{CT}$ \\
\hline $\mathrm{LSC}^{*}$ & $\begin{array}{l}\text { Shahin et al. } \\
\text { (2016) }\end{array}$ & $\mathrm{D}$ & RE.U & & RFID & \\
\hline LSC & $\begin{array}{l}\text { So and Sun } \\
\text { (2010) }\end{array}$ & $\mathrm{D}$ & RE.U & & E-BUS & \\
\hline LSC & $\begin{array}{l}\text { So and Sun } \\
\text { (2011) }\end{array}$ & I & RE.U & & E-BUS & IDT \\
\hline
\end{tabular}


Table 6 (continued)

\begin{tabular}{|c|c|c|c|c|c|c|}
\hline \multirow[t]{2}{*}{ Strategy } & \multirow[t]{2}{*}{ Papers } & \multirow[t]{2}{*}{ Approach } & \multirow[t]{2}{*}{ Conceptualization } & \multicolumn{2}{|c|}{ Measurement } & \multirow[t]{2}{*}{ Theory } \\
\hline & & & & Aggregate & Specific IT & \\
\hline LSC & $\begin{array}{l}\text { Zelbst et al. } \\
\qquad(2014)\end{array}$ & $\mathrm{D} / \mathrm{I}$ & RE.U & & RFID & ST \\
\hline ASC & $\begin{array}{l}\text { Almahamid and } \\
\text { Hourani } \\
(2015)\end{array}$ & $\mathrm{D}, \mathrm{I}$ & RE.U & & ERP/E-BUS & \\
\hline ASC & $\begin{array}{l}\text { Al-Nimer } \\
\text { (2019) }\end{array}$ & $\mathrm{D}$ & RE.U & & ERP & \\
\hline ASC & $\begin{array}{l}\text { Bargshady et al. } \\
\quad(2016)\end{array}$ & $\mathrm{D}$ & CAP & AGGRE & & \\
\hline ASC & Bi et al. (2013) & I & CAP & AGGRE & & RBV \\
\hline ASC & Brusset (2016) & $\mathrm{D}$ & CAP & AGGRE & & $\mathrm{RBV} / \mathrm{DC}$ \\
\hline ASC & Chen (2019) & $\mathrm{D}$ & CAP & AGGRE & & $\mathrm{RBV} / \mathrm{DC}$ \\
\hline $\mathrm{ASC}^{*}$ & $\begin{array}{l}\text { Chiarini and } \\
\text { Vagnoni } \\
(2017)\end{array}$ & D- & RE.U & & ERP & \\
\hline ASC & $\begin{array}{l}\text { DeGroote and } \\
\text { Marx (2013) }\end{array}$ & $\mathrm{D}$ & RE.U & AGGRE & & \\
\hline ASC & $\begin{array}{l}\text { Dehgani and } \\
\text { Navimipour } \\
(2019)\end{array}$ & $\mathrm{D}$ & CAP & AGGRE & & \\
\hline ASC & $\begin{array}{l}\text { Ding et al. } \\
\text { (2012) }\end{array}$ & $\mathrm{C}-$ & CAP & AGGRE & & $\mathrm{RBV}$ \\
\hline ASC & $\begin{array}{l}\text { Dubey et al. } \\
(2019 a)\end{array}$ & $\mathrm{D}$ & $\mathrm{CAP}+$ & & BIG D & $\mathrm{DC} / \mathrm{CT}$ \\
\hline ASC & $\begin{array}{c}\text { García-Alcaraz } \\
\text { et al. (2017) }\end{array}$ & $\mathrm{D}$ & RE.U & AGGRE & & \\
\hline ASC & $\begin{array}{c}\text { García-Alcaraz } \\
\text { et al. (2019) }\end{array}$ & $\mathrm{D}$ & CAP & AGGRE & & \\
\hline ASC* & $\begin{array}{c}\text { Ghobakhloo and } \\
\text { Azar (2018a) }\end{array}$ & $\mathrm{D}$ & RE.U & & AMT & \\
\hline ASC* & $\begin{array}{c}\text { Ghobakhloo and } \\
\text { Azar (2018b) }\end{array}$ & $\mathrm{D}$ & RE.I/CAP & AGGRE & & $\begin{array}{l}\text { RBV/ } \\
\text { Tcomp }\end{array}$ \\
\hline ASC* & $\begin{array}{l}\text { Gorane and } \\
\text { Kant (2017) }\end{array}$ & I & RE.U & AGGRE & & \\
\hline ASC & $\begin{array}{l}\text { Hwang and Rho } \\
\text { (2016) }\end{array}$ & $\mathrm{D}$ & CAP & & RFID & $\begin{array}{r}\text { RBV/ } \\
\text { SCT }\end{array}$ \\
\hline ASC & $\begin{array}{l}\text { Kabra and } \\
\text { Ramesh } \\
(2016)\end{array}$ & $\mathrm{D}$ & RE.U & AGGRE & & \\
\hline ASC & $\begin{array}{l}\text { Kumar et al. } \\
\text { (2017) }\end{array}$ & $\mathrm{D}$ & RE.U & AGGRE & & \\
\hline ASC & Liu et al. (2013) & I & CAP & AGGRE & & $\mathrm{DC}$ \\
\hline
\end{tabular}


Table 6 (continued)

\begin{tabular}{|c|c|c|c|c|c|c|}
\hline \multirow[t]{2}{*}{ Strategy } & \multirow[t]{2}{*}{ Papers } & \multirow[t]{2}{*}{ Approach } & \multirow[t]{2}{*}{ Conceptualization } & \multicolumn{2}{|c|}{ Measurement } & \multirow[t]{2}{*}{ Theory } \\
\hline & & & & Aggregate & Specific IT & \\
\hline ASC & Liu et al. (2018) & $\mathrm{D}$ & CAP & & CLOUD & \\
\hline ASC & Mandal (2018) & $\mathrm{D}$ & CAP & & BIG D & $\mathrm{RBV} / \mathrm{DC}$ \\
\hline ASC & Mandal (2019a) & $\mathrm{D}$ & CAP & AGGRE & & $\mathrm{DC}$ \\
\hline ASC & Mandal (2019b) & $\mathrm{D}$ & CAP & & BIG D & $\mathrm{RBV} / \mathrm{DC}$ \\
\hline ASC & $\begin{array}{l}\text { Motadel et al. } \\
\text { (2011) }\end{array}$ & $\mathrm{D}$ & CAP & AGGRE & & \\
\hline ASC & Oh et al. (2019) & $\mathrm{C}-$ & RE.U & & E-BUS & \\
\hline ASC & $\begin{array}{l}\text { Panichayakorn } \\
\text { and Jermsitti- } \\
\text { parsert } \\
(2019)\end{array}$ & $\mathrm{D}$ & RE.U & AGGRE & & RBV \\
\hline ASC & $\begin{array}{l}\text { Paulraj and } \\
\text { Chen (2007) }\end{array}$ & I & RE.U & AGGRE & & \\
\hline ASC & $\begin{array}{l}\text { Pool et al. } \\
\text { (2018) }\end{array}$ & $\mathrm{D}$ & RE.U & & BI & TOE \\
\hline ASC* & $\begin{array}{l}\text { Qrunfleh and } \\
\text { Tarafdar } \\
(2014)\end{array}$ & $\mathrm{C}$ & CAP & AGGRE & & IPT \\
\hline ASC* & $\begin{array}{l}\text { Qrunfleh et al. } \\
\text { (2012) }\end{array}$ & $\mathrm{C}^{0}$ & CAP & AGGRE & & $\mathrm{CT}$ \\
\hline ASC & $\begin{array}{l}\text { Rahimi et al. } \\
\text { (2019) }\end{array}$ & $\mathrm{D}$ & RE.U & AGGRE & & \\
\hline ASC & $\begin{array}{c}\text { Samdantsoodol } \\
\text { et al. (2017) }\end{array}$ & D-, I & RE.U & AGGRE & & RBV \\
\hline ASC & $\begin{array}{l}\text { Samizadeh et al. } \\
\text { (2019) }\end{array}$ & $\mathrm{D}$ & CAP & AGGRE & & \\
\hline ASC & $\begin{array}{l}\text { Sangari and } \\
\text { Razmi (2015) }\end{array}$ & $\mathrm{D}$ & CAP & & $\mathrm{BI}$ & $\mathrm{RBV} / \mathrm{DC}$ \\
\hline ASC & $\begin{array}{r}\text { Schniederjans } \\
\text { et al. (2016) }\end{array}$ & I & RE.U & & CLOUD & $\begin{array}{l}\text { SCT/ } \\
\text { TAM }\end{array}$ \\
\hline $\mathrm{ASC}^{*}$ & $\begin{array}{l}\text { Shahin et a. } \\
\text { (2016) }\end{array}$ & $\mathrm{D}$ & RE.U & & RFID & \\
\hline ASC & $\begin{array}{l}\text { Sheel and Nath } \\
\text { (2019) }\end{array}$ & $\mathrm{D}$ & CAP & & BLOCK & $\mathrm{RBV} / \mathrm{DC}$ \\
\hline ASC & $\begin{array}{l}\text { Swafford et al. } \\
\text { (2008) }\end{array}$ & I & CAP & AGGRE & & RBV \\
\hline ASC & $\begin{array}{l}\text { Tarafdar and } \\
\text { Qrunfleh } \\
(2017)\end{array}$ & $\mathrm{C}$ & CAP & AGGRE & & $\begin{array}{l}\text { Tcomp/ } \\
\text { IPT }\end{array}$ \\
\hline ASC & $\begin{array}{l}\text { Vagnoni and } \\
\text { Khoddami } \\
(2016)\end{array}$ & $\mathrm{D}$ & CAP & AGGRE & & $\mathrm{DC}$ \\
\hline ASC & $\begin{array}{l}\text { Vickery et al. } \\
\text { (2010) }\end{array}$ & $\mathrm{D}^{0}$ & RE.U & AGGRE & & Tcomp \\
\hline ASC & $\begin{array}{l}\text { Wamba and } \\
\text { Akter (2019) }\end{array}$ & $\mathrm{D}$ & $\mathrm{CAP}+$ & & BIG D & $\mathrm{RBV} / \mathrm{DC}$ \\
\hline
\end{tabular}


Table 6 (continued)

\begin{tabular}{|c|c|c|c|c|c|c|}
\hline \multirow[t]{2}{*}{ Strategy } & \multirow[t]{2}{*}{ Papers } & \multirow[t]{2}{*}{ Approach } & \multirow[t]{2}{*}{ Conceptualization } & \multicolumn{2}{|c|}{ Measurement } & \multirow[t]{2}{*}{ Theory } \\
\hline & & & & Aggregate & Specific IT & \\
\hline ASC & $\begin{array}{l}\text { Wamba et al. } \\
(2020)\end{array}$ & $\mathrm{D}$ & $\mathrm{CAP}+$ & & BIG D & $\mathrm{DC}$ \\
\hline ASC & Yang (2014) & $\mathrm{D}$ & CAP & AGGRE & & IPT/ TCE \\
\hline ASC & $\begin{array}{l}\text { Yusuf et al. } \\
\text { (2004) }\end{array}$ & $\mathrm{D}$ & RE.U & & E-BUS & \\
\hline
\end{tabular}

Strategy: LSC, Lean supply chain; ASC, Agile supply chain; (*) Papers that address both strategies; Approach: D, Direct; I, Indirect; C, Complementary; $(-)$ Negative; $\left({ }^{0}\right)$ Non-significant; Conceptualization: RE.I, Resource-IT investment; RE.U, Resource-IT use; CAP, Capability; CAP ${ }^{+}$, Higher-order capability; Measurement: AGGRE, Aggregated terms; E-BUS, E-Business technologies; ERP, Enterprise resource planning; AMT, Advanced manufacturing technologies; RFID, Radio frequency identification; BI, Business intelligence; BLOCK, Blockchain; CLOUD, Cloud computing; BIG D, Big data; Theory: RBV, Resource-based view; Tcomp, Theory of complementarity; ValueCT, Value co-creation theory; IPT, Information processing theory; CT, Contingency theory; IDT, Innovation diffusion theory; ST, Systems theory; DC, Dynamic capabilities; SCT, Social capital theory; TOE, Technology-organization-environment; TAM, Technology adoption model; TCE, Transaction cost economics

Three main observations can be highlighted considering these data. First, most of the papers that measure IT as a capability have found a direct IT-ASC relationship. These results are mainly confirmed when IT capability is measured as an aggregate and as a Big Data Analytics (BDA) capability. In this regard, papers grounded in Dynamic Capabilities consider SCA to be a higher-order capability derived from other lower-order capabilities, such as IT capability. The most-investigated features of IT capability are IT integration and IT flexibility. Only in the case of BDA capability is it assumed (in 3 papers) to be a higher-order capability. In this sense, this specific IT capability directly affects both ASC and firm performance. One illustrative example is Netflix's BDA capability, which enables the company to quickly analyze mass user data to identify customer behavior and predict trends and, thus, nurture customer satisfaction and improve sales (Wamba et al., 2020).

Second, most of the papers that measure IT use are not based on existing theories. However, they also mainly found a positive and direct relationship between IT and ASC, while a few studies that used aggregated terms or specific technologies found an indirect relationship.

Finally, the minority of the papers (6) found negative or non-significant results for IT's effect on ASC. Four of these studies conceptualize IT as a resource (IT use). Two ideas can be drawn from these studies: On the one hand, negative or non-significant effects are found by measuring the use of one specific type of IT when this technology is unable to meet the supply chain's needs for agility (Chiarini \& Vagnoni, 2017; Oh et al., 2019). On the other hand, some results state that IT must be combined with other firm or SC capabilities (i.e., the creation of a virtual enterprise, absorptive capacity, and SC integration) (Samdantsoodol et al., 2017; Vickery et al., 2010). In this sense, the theory of complementarity (Milgrom \& Roberts, 1995) helps to explain that it is not IT alone that leads to enhanced ASC but IT's interaction with complementary capabilities.

\subsection{Gaps and challenges for future research}

In the previous subsections, survey-based research related to IT and the two supply chain strategies has been analyzed and synthesized to identify what is being studied in these research 
areas. A framework for future research has been developed based on the findings of the study. We summarize the main topics as follows:

(a) Use of consolidated theoretical perspectives There is a lack of use of existing theories, mainly in the IT-LSC literature but also in IT-ASC studies. The use of theoretical lenses can provide a better understanding of the underlying complexity of the relationship between constructs. Thus, future studies should incorporate the theoretical perspectives already used in other papers in this review, including RBV, Dynamic Capabilities, and the Theory of Complementarity. Researchers could also adopt other theories used in Operations Management studies. In this regard, Institutional Theory (DiMaggio \& Powell, 1983) and Resource Orchestration Theory (Sirmon et al., 2011) might offer a useful framework to understand how SC can build and configure resources and capabilities (such as IT aligned with the supply strategy) to obtain a competitive advantage.

According to Institutional Theory, organizations facing the same environmental conditions can be influenced to adopt the same structures and ways of working (DiMaggio \& Powell, 1983). Therefore, institutional pressures can drive companies to adopt specific technologies or develop certain capabilities in their supply chains (Dubey et al., 2019b). This is an important issue to consider in global supply chains, where companies from different countries may experience distinct pressures, which in turn can have an effect on their supply chain strategy deployment.

Resource Orchestration Theory (ROT) is an extension of the resource-based view that overcomes its limitations (Sirmon et al., 2011). ROT considers that the development of competitive advantage depends on the ability of managers to generate synergistic effects through the deployment of resources and capabilities (Sirmon et al., 2011). So, it can be extrapolated to the SC level (Rojo et al., 2020), and could be used to understand how managers can orchestrate, i.e., identify, bundle and leverage, different IT supply chain resources and capabilities to achieve better results in Lean and Agile contexts.

(b) IT features and their impacts on LSC/ASC: The reviewed literature conceptualizes IT as a resource and as a capability. We understand that both views are important for understanding the underlying processes of IT's impact. However, the research results reveal the need to reinforce research and explore new ideas in some areas.

IT as a resource: The role of emerging technologies (Industry 4.0 technologies and digital technologies), can be meaningfully measured as IT use since they are IT in a nascent process of adoption, and many SCs have not developed specific capabilities related to their adoption. In this view, Institutional Theory could be used for the study of the institutional pressures that can lead to IT adoption. Besides, measuring IT as a specific technology may provide insights into how and which technologies are suitable for supporting LSC/ASC practices. In this sense, the role of some (specific) emerging technologies of Industry 4.0 stands out in the ASC research, but not in the LSC research. Therefore, as there is a need for Digital Technologies in modern manufacturing systems, the role of emerging IT (e.g., Internet of Things, Cloud Computing, Big Data, Blockchain, Artificial Intelligence, 3D printing) in extending Lean practices across the $\mathrm{SC}$, could be explored.

Another avenue for future research might be to compare the functions of specific technologies. In this sense, some studies have differentiated between ERP and e-business technologies (Almahamid \& Hourani, 2015; Hong et al., 2010). It would, therefore, be interesting to compare and analyze how different types of IT can affect LSC and/or ASC strategy, as this would provide knowledge of the context or situation in which IT is more effective for one strategy or the other. On the other hand, it is also true that technologies 
are rarely implemented alone. Thus, the joint role of these different types of IT should also be considered. A further avenue for future research could be to compare the roles of individual technologies and combined technologies linked to Industry 4.0 in the LSC context (as other previous studies, e.g., Núñez-Merino et al. (2020), indicate) and in the ASC context.

IT as capability: According to a few studies, IT efficiency capability is an important feature for LSC. However, the role of IT capabilities was less developed in the LSC context than in the ASC context and some questions remain unanswered. Thus, it may be useful to understand how other IT capabilities such as IT flexibility and BDA capability can support Lean practices. Moreover, due to the disruptive changes related to Industry 4.0 that SCs are facing, future studies on LSC/ASC should consider the digital supply chain capability (Queiroz et al., 2021). This could offer a holistic view of the way that the digitalization of SC processes interacts with each of the SC strategies.

Further, if they are grounded in the aforementioned theories, futures studies could examine how to build these IT capabilities and how to orchestrate SC resources.

(c) IT indirect effects on LSC/ASC As demonstrated by some of the studies in this review, the effects of IT on LSC/ASC can be perceived via indirect effects, i.e., by the mediation of other variables such as SC integration, SC flexibility, and SC absorptive capacity. This means that there are multiple processes in SC that must be properly configured to achieve the results sought with each of the SC strategies and, ultimately, to achieve better performance (Maqueira et al., 2021). Therefore, the complexity of supply chain processes means that other capabilities can help to explain the IT-LSC/ASC relationships. In this regard, futures studies should analyze the role of SC ambidexterity, i.e., the ability to integrate and reconfigure both the firm's and the suppliers' resources through the simultaneous exploration of new opportunities and the exploitation of existing competencies (Rojo et al., 2020). Previous studies have recently demonstrated that IT capabilities facilitate exploration and exploitation processes at the supply chain level (Rojo et al., 2020). Further, some studies suggest that Lean implementation requires a certain level of ambidexterity (Secchi \& Camuffo, 2016) and that SC ambidexterity can increase the detection of changes in the environment and speed up reactions to (Rojo et al., 2020), both critical skills for an agile supply chain. In this view, using ROT lenses, future studies could analyze (a) the potential of IT capabilities to enable SCs to orchestrate their resources (IT $\rightarrow$ SC ambidexterity), and (b) the ability to translate SC ambidexterity into enhanced LSC/ASC (SC ambidexterity $\rightarrow$ LSC/ASC). These efforts could help to understand the IT indirect effects and might also explain the contradictory results found in previous studies.

(d) IT-enabled LSC/ASC and performance It seems clear that LSC and ASC have positive effects on business performance (see Tables 4 and 5, relationship F). However, most of the studies have adopted financial and operational focuses and have overlooked environmental and social aspects (Kamble et al. 2020 is an exception). Therefore, there is a lack of theoretical understanding of how IT-enabled LSC/ASC impact sustainable business performance. Previous studies have demonstrated that lean practices are related to employee welfare (Baliga et al., 2019) and positively impact sustainable sourcing and production practices; however, the same practices negatively impact sustainable logistics operations (Jakhar et al., 2018). Further, some scholars indicate that agile practices rely on a capacity surplus to improve the supply chain's ability to respond to changes in customer's needs and this could negatively affect sustainability performance (Ciccullo 
et al., 2018). In this sense, further studies should be conducted to confirm these impacts and, if applicable, analyze whether IT could reduce these trade-offs and how.

Moreover, as Lean and Agile can be considered complementary strategies (Christopher, 2000; Goldsby et al., 2006), further understanding of the role of IT in the two strategies will provide important insights. Future studies could comparatively analyze the relationship between IT and LSC/ASC, their joint or synergistic effect with IT support, and how their joint implementation can affect performance. This would allow us to deduce where IT both meets the goals targeted with the SC strategy and improves company-level performance.

\section{Conclusions and implications}

The purpose of this paper was to understand how the way that IT is conceptualized affects its role in Lean and Agile SC strategies and whether there is a consequential effect on performance. This has resulted in directions being given to improve theory development in the area. For this, a Systematic Literature Review has been carried out that has enabled the identification and analysis of 59 survey-based articles on the addressed topics.

First, the findings of the study highlight the fact that the survey-based research literature on IT-ASC is more developed in terms of quantity than that on IT-LSC. One possible explanation could be that the Lean literature mostly focuses on internal aspects rather than on customer and supplier integration issues (Marodin et al., 2017). Another explanation could be that the research appears to regard IT more as a mechanism that provides agility than leanness or that reduces inefficiencies along the SC. Hence, it seems that researchers have overlooked the fact that IT could also be helpful in LSC contexts as it provides flexibility, automation, and a more efficient decision-making process in the SC.

Second, the study shows that some relationships have been repeatedly tested in the literature, while others have been explored to a very limited extent or not at all. In general, the combination of IT use and the implementation of LSC or ASC can have a positive effect on business performance. However, it can be inferred that there is no general agreement as to the way that IT and LSC interact, i.e., interaction can be mainly through direct and complementary relationships, or how different features of IT can impact LSC. As a considerable number of the studies conceptualize IT as a resource (often as an aggregate) without any consolidated theoretical foundations, limited specific deductions can be drawn. Overall, this review has found more support for the positive effects of IT on LSC than not. At the same time, these results demonstrate that the relationship between IT and Lean can be more complex than a direct effect and that the outcomes can be achieved under different conditions.

On the other hand, this study has identified that the direct effect of IT on ASC is the most prominent approach in this context. When IT is conceptualized as a capability, IT integration, IT flexibility, and Big Data Analytics capabilities stand out. These results give indications of important IT features that supply chains need to have to achieve ASC goals. However, the literature on IT-ASC presents some limitations, including contradictory results, the lack of the use of consolidated theories to underpin them when IT is conceptualized as a resource, and a narrow focus on performance. Conflicting results are especially found when IT is measured as a resource (IT use). Besides, the direct effects of IT are slightly stronger when IT is considered as a capability. This seems to suggest that as a resource, IT by itself has less impact on ASC than IT capabilities, as has been shown to be the case with the IT effect on performance or competitive advantage (Powell \& Dent-Micallef, 1997; Yu et al., 2017). 
Therefore, concerning the three stages of IT use, we found that IT investment is not a common conceptualization and has only been used in a few studies to understand the effect of IT investments on IT capability-building. In this sense, the reviewed literature is in line with the previous research on IT strategic literature, which considers that IT investments alone are unable to transfer to performance. Furthermore, the conceptualization of IT as a capability is more widely adopted in the ASC studies than in the LSC studies. This finding shows that the research on IT-ASC has adopted a more dynamic view of supply chain processes than that on IT-LSC. This is also reflected in the theoretical choices of each research domain. While the literature on IT-ASC has used RBV and the theory of Dynamic Capabilities, the research on IT-LSC has used RBV in only a few studies and in a large number of papers the relationship has not been supported by any theory.

Based upon existing work and the gaps detected, we have developed a framework with four main points to provide directions for future research. Thus, to make futures studies more meaningful, this review encourages researchers to use theories adopted in the field of strategic management (Institutional Theory and ROT). These theories can help to understand important issues for progressing toward a greater digital supply chain capability aligned with the objectives of Lean/Agile supply chain strategies and sustainable performance goals. For this, researchers could investigate the use of emerging technologies, the way that supply chains are able to build IT capabilities, and the role of other SC capabilities such as SC ambidexterity. Furthermore, future studies could explore the alignment between IT internal and suppliers capabilities and LSC and ASC strategies to create a synergy effect, which could be different depending on the decoupling point. These future avenues of investigation could help understand how to configure the SC in the most appropriate way and which technologies and capabilities might be more suitable depending on the goals targeted.

As a practical contribution, this review offers a summary of the current body of knowledge that can be used by managers to support decision-making on the use of IT in LSC and ASC strategies. The study also indicates that a direct impact of IT on performance is less frequent but, if it is appropriately accompanied by LSC or ASC strategies, together they can boost performance. In this sense, some evidence shows that the use of a group of technologies and, more specifically, the use of e-business technologies, RFID, and AMT gives the supply chain flexibility by fulfilling LM objectives. At the same time, there is no doubt about the crucial role of IT in improving ASC implementation. More specifically, capabilities such as BDA, IT integration, and IT flexibility seem to have a direct effect on agility, while the use of other types of mature IT can do so indirectly or require the support of other SC capabilities. So, managers should invest in improving IT capabilities and developing other SC capabilities.

Lastly, it must be stated that the present SLR is not without its limitations. The inclusion and exclusion criteria used have influenced the results that have been obtained. Furthermore, SLR is criticized for the subjectivity of its search keyword selection. Notwithstanding this, the involvement of several researchers and the consensus that they arrived at in the choice of search keywords reduces the bias associated with the subjectivity of a single researcher (Thomé et al., 2016). Another limitation is the exclusive selection of quantitative empirical articles, which restricts the perception of the phenomenon using other methodological approaches. However, while qualitative techniques are recognized as effective for exploring or describing little-known phenomena, theoretical models are preferably explained with quantitative techniques (Zhang et al., 2011).

Funding Open Access funding provided thanks to the CRUE-CSIC agreement with Springer Nature. The authors acknowledge the financial support of Spanish Ministry of Science, Innovation and Universities 
(Research Project PID2019-106577 GB-I00 by MCIN/AEI/10.13039/501100011033), UJA-FEDER Andalusian Operational Program (Research Project 1261128) and Andalusian Plan for Research, Development and Innovation-PAIDI 2020 (Research Project P20-00794).

\section{Declarations}

Conflict of interest No potential conflict of interest was reported by the authors.

Open Access This article is licensed under a Creative Commons Attribution 4.0 International License, which permits use, sharing, adaptation, distribution and reproduction in any medium or format, as long as you give appropriate credit to the original author(s) and the source, provide a link to the Creative Commons licence, and indicate if changes were made. The images or other third party material in this article are included in the article's Creative Commons licence, unless indicated otherwise in a credit line to the material. If material is not included in the article's Creative Commons licence and your intended use is not permitted by statutory regulation or exceeds the permitted use, you will need to obtain permission directly from the copyright holder. To view a copy of this licence, visit http://creativecommons.org/licenses/by/4.0/.

\section{References}

\section{*SLR References}

*Ahmad, S., \& Schroederc, R. G. (2001). The impact of electronic data interchange on delivery performance. Production and Operations Management, 10(1), 16-30.

*Almahamid, S., \& Hourani, A. (2015). An empirical study on the impacts of ERP system, e-business technologies and organizational collaboration on supply chain agility: PLS perspective. International Journal of Advanced Operations Management, 7(3), 229-254.

*Al-Nimer, M. (2019). Examining the mediating role of agile supply chain approach between ERP system implementation and organizational performance. International Journal of Supply Chain Management, 8(4), 107-118.

Baliga, R., Raut, R., \& Kamble, S. (2019). The effect of motivators, supply, and lean management on sustainable supply chain management practices and performance: Systematic literature review and modeling. Benchmarking, 27(1), 347-381.

*Bargshady, G., Zahraee, S. M., Ahmadi, M., \& Parto, A. (2016). The effect of information technology on the agility of the supply chain in the Iranian power plant industry. Journal of Manufacturing Technology Management, 27(3), 427-442.

Barney, J. (1991). Firm resources and sustained competitive advantage. Journal of Management, 17(1), 99-120.

*Bayraktar, E., Demirbag, M., Koh, S. C. L., Tatoglu, E., \& Zaim, H. (2009). A causal analysis of the impact of information systems and supply chain management practices on operational performance: Evidence from manufacturing SMEs in Turkey. International Journal of Production Economics, 122(1), 133-149.

*Bayraktar, E., Gunasekaran, A., Koh, S. C. L., Tatoglu, E., Demirbag, M., \& Zaim, S. (2010). An efficiency comparison of supply chain management and information systems practices: A study of Turkish and Bulgarian small- and medium-sized enterprises in food products and beverages. International Journal of Production Research, 48(2), 425-451.

Bharadwaj, A. S. (2000). A resource-based perspective on information technology capability and firm performance. MIS Quarterly, 24(1), 169-196.

*Bi, R., Davidson, R., Kam, B., \& Smyrnios, K. (2013). Developing organizational agility through IT and supply chain capability. Journal of Global Information Management, 21(4), 38-55.

Boaden, R., \& Lockett, G. (1991). Information technology, information systems and information management: Definition and development. European Journal of Information Systems, 1(1), 23-32.

Boyd, B. K., Haynes, K. T., Hitt, M. A., Bergh, D. D., \& Ketchen, D. J. (2012). Contingency hypotheses in strategic management research: Use, disuse, or misuse? Journal of Management, 38(1), 278-313.

Bruce, M., Daly, L., \& Towers, N. (2004). Lean or agile: A solution for supply chain clothing industry ? International Journal of Operations and Production Management, 24(2), 151-170.

*Brusset, X. (2016). Does supply chain visibility enhance agility? International Journal of Production Economics, 171, 46-59. 
Calatayud, A., Mangan, J., \& Christopher, M. (2019). The self-thinking supply chain. Supply Chain Management: An International Journal, 24(1), 22-38.

*Chen, C. J. (2019). Developing a model for supply chain agility and innovativeness to enhance firms' competitive advantage. Management Decision, 57(7), 1511-1534.

*Chiarini, A., \& Vagnoni, E. (2017). Strategies for modern operations management: Answers from European manufacturing companies. Benchmarking, 24(4), 1065-1081.

Chicksand, D., Watson, G., Walker, H., Radnor, Z., \& Johnston, R. (2012). Theoretical perspectives in purchasing and supply chain management: An analysis of the literature. Supply Chain Management: An International Journal, 17, 454-472.

Christopher, M. (2000). The agile supply chain: Competing in volatile markets. Industrial Marketing Management, 29(1), 37-44.

Ciccullo, F., Pero, M., Caridi, M., Gosling, J., \& Purvis, L. (2018). Integrating the environmental and social sustainability pillars into the lean and agile supply chain management paradigms: A literature review and future research directions. Journal of Cleaner Production, 172, 2336-2350.

Danese, P., Manfè, V., \& Romano, P. (2018). A systematic literature review on recent lean research: State-ofthe-art and future directions. International Journal of Management Reviews, 20(2), 579-605.

*DeGroote, S. E., \& Marx, T. G. (2013). The impact of IT on supply chain agility and firm performance: An empirical investigation. International Journal of Information Management, 33(6), 909-916.

*Dehgani, R., \& Navimipour, J. N. (2019). The impact of information technology and communication systems on the agility of supply chain management systems. Kybernetes, 48(10), 2217-2236.

Denyer, D., \& Tranfield, D. (2009). Producing a Systematic Review. In The SAGE Handbook of Organizational Research Methods (pp. 671-689). London: Sage Publications

Devaraj, S., \& Kohli, R. (2003). Performance impacts of information technology: Is actual usage the missing link? Management Science, 49(3), 273-289.

DiMaggio, P. J., \& Powell, W. W. (1983). The iron cage revisited: Institutional isomorphism and collective rationality in organizational fields. American Sociological Review, 48(2), 147-160.

*Ding, M. J., Kam, B. H., \& Lalwani, C. S. (2012). Operational routines and supply chain competencies of Chinese logistics service providers. International Journal of Logistics Management, 23(3), 383-407.

Dubey, R., Bryde, D. J., Foropon, C., Graham, G., Giannakis, M., \& Mishra, D. B. (2020). Agility in humanitarian supply chain: an organizational information processing perspective and relational view. Annals of Operations Research, In press. Doi: https://doi.org/10.1007/s10479-020-03824-0.

*Dubey, R., Gunasekaran, A., \& Childe, S. J. (2019a). Big data analytics capability in supply chain agility: The moderating effect of organizational flexibility. Management Decision, 57(8), 2092-2112.

Dubey, R., Gunasekaran, A., Childe, S. J., Blome, C., \& Papadopoulos, T. (2019b). Big data and predictive analytics and manufacturing performance: Integrating institutional theory, resource-based view and big data culture. British Journal of Management, 30(2), 341-361.

Durach, C. F., Kembro, J., \& Wieland, A. (2017). A new paradigm for systematic literature reviews in supply chain management. Journal of Supply Chain Management, 53(4), 67-85.

*García-Alcaraz, J. L., Martínez-Loya, V., Díaz-Reza, J. R., Blanco-Fernández, J., Jiménez-Macías, E., \& López, A. J. G. (2019). Effect of ICT integration on SC flexibility, agility and company' performance: the Mexican maquiladora experience. Wireless Networks, In press.

*García-Alcaraz, J. L., Maldonado-Macías, A. A., Alor-Hernández, G., \& Sánchez-Ramírez, C. (2017). The impact of information and communication technologies (ICT) on agility, operating, and economical performance of supply chain. Advances in Production Engineering and Management, 12(1), 29-40.

Ghobakhloo, M. (2020). Determinants of information and digital technology implementation for smart manufacturing. International Journal of Production Research, 38(8), 2384-2405.

*Ghobakhloo, M., \& Azar, A. (2018a). Business excellence via advanced manufacturing technology and lean-agile manufacturing. Journal of Manufacturing Technology Management, 29(1), 2-24.

*Ghobakhloo, M., \& Azar, A. (2018b). Information technology resources, the organizational capability of lean-agile manufacturing, and business performance. Information Resources Management Journal, 31(2), 47-74.

*Ghobakhloo, M., Fathi, M., Fontes, D. B. M. M., \& Tan Ching, N. (2018). Modeling lean manufacturing success. Journal of Modelling in Management, 13(4), 908-931.

*Ghobakhloo, M., \& Hong, T. S. (2014). IT investments and business performance improvement: The mediating role of lean manufacturing implementation. International Journal of Production Research, 52(18), 5367-5384.

Gligor, D. M., \& Holcomb, M. C. (2012). Understanding the role of logistics capabilities in achieving supply chain agility: A systematic literature review. Supply Chain Management, 17(4), 438-453.

Goldsby, T. J., Griffis, S. E., \& Roath, A. S. (2006). Modeling lean, agile, and leagile supply chain strategies. Journal of Business Logistics, 27(1), 57-78. 
*Gorane, S., \& Kant, R. (2017). Supply chain practices and organizational performance. The International Journal of Logistics Management, 28(1), 75-101.

*Hong, P. C., Dobrzykowski, D. D., \& Vonderembse, M. A. (2010). Integration of supply chain IT and lean practices for mass customization. Benchmarking: An International Journal, 17(4), 561-592.

Humdan, E. A., Shi, Y., \& Behnia, M. (2020). Supply chain agility : A systematic review of definitions, enablers and performance implications. International Journal of Physical Distribution \&amp; Logistics Management, 50(2), 287-312.

*Hwang, Y. M., \& Rho, J. J. (2016). Strategic value of RFID for inter-firm supply chain networks: An empirical study from a resource and social capital perspective. Information Development, 32(3), 509-526.

Ivanov, D. (2020). Viable supply chain model: integrating agility, resilience and sustainability perspectives-lessons from and thinking beyond the COVID-19 pandemic. Annals of Operations Research, In press. Doi: https://doi.org/10.1007/s10479-020-03640-6

Jakhar, S. K., Rathore, H., \& Mangla, S. K. (2018). Resources, conservation \& recycling is lean synergistic with sustainable supply chain? An empirical investigation from emerging economy. Resources, Conservation \&amp; Recycling, 139, 262-269.

* Kabra, G., \& Ramesh, A. (2016). Information technology, mutual trust, flexibility, agility, adaptability: Understanding their linkages and impact on humanitarian supply chain management performance. Risk, Hazards and Crisis in Public Policy, 7(2), 79-103.

*Kamble, S., Gunasekaran, A., \& Dhone, N. C. (2020). Industry 4.0 and lean manufacturing practices for sustainable organisational performance in Indian manufacturing companies. International Journal of Production Research, 58(5), 1319-1337.

*Karakadilar, I. S., \& Hicks, B. J. (2015). Exploring the moderating role of lean production on supplier performance: An empirical study of Turkish automotive part suppliers. Bogazici Journal, 29(2), 73-97.

Karlsson, C. (2010). Researching operations management. Routledge.

*Khanchanapong, T., Prajogo, D., Sohal, A. S., Cooper, B. K., Yeung, A. C. L., \& Cheng, T. C. E. (2014). The unique and complementary effects of manufacturing technologies and lean practices on manufacturing operational performance. International Journal of Production Economics, 153, 191-203.

Kharub, M., Mor, R. S., \& Sharma, R. (2019). The relationship between cost leadership competitive strategy and firm performance: A mediating role of quality management. Journal of Manufacturing Technology Management, 30(6), 920-936.

*Kou, T. C., Chiang, C. T., \& Chiang, A. H. (2018). Effects of IT-based supply chains on new product development activities and the performance of computer and communication electronics manufacturers. Journal of Business and Industrial Marketing, 33(7), 869-882.

*Kumar, V., Verma, P., Sharma, R. R. K., \& Khan, A. F. (2017). Conquering in emerging markets: Critical success factors to enhance supply chain performance. Benchmarking, 24(3), 570-593.

Lalmazloumian, M., Wong, K. Y., Govindan, K., \& Kannan, D. (2016). A robust optimization model for agile and build-to-order supply chain planning under uncertainties. Annals of Operations Research, 240(2), 435-470.

Lamming, R. (1996). Squaring lean supply with supply chain management. International Journal of Operations and Production Management, 16(2), 183-196.

Lee, H. L. (2002). Aligning supply chain strategies with product uncertainties. California Management Review, 44(3), 105-119.

Li, Y., Diabat, A., \& Lu, C. C. (2020). Leagile supplier selection in Chinese textile industries: A DEMATEL approach. Annals of Operations Research, 287(1), 303-322.

*Liu, H., Ke, W., Wei, K. K., \& Hua, Z. (2013). The impact of IT capabilities on firm performance: The mediating roles of absorptive capacity and supply chain agility. Decision Support Systems, 54(3), 1452-1462.

*Liu, S., Chan, F. T. S., Yang, J., \& Niu, B. (2018). Understanding the effect of cloud computing on organizational agility: An empirical examination. International Journal of Information Management, 43, 98-111.

* Mandal, S. (2018). An examination of the importance of big data analytics in supply chain agility development: A dynamic capability perspective. Management Research Review, 41(10), 1201-1219.

*Mandal, S. (2019a). Exploring the influence of IT capabilities on agility and resilience in tourism: Moderating role of technology orientation. Journal of Hospitality and Tourism Technology, 10(3), 431-444.

*Mandal, S. (2019b). The influence of big data analytics management capabilities on supply chain preparedness, alertness and agility: An empirical investigation. Information Technology and People, 32(2), 297-318.

Maqueira, J. M. M., Novais, L., \& Bruque-Cámara, S. (2021). Total eclipse on business performance and mass personalization: How supply chain flexibility eclipses lean production direct effect. Supply Chain Management: An International Journal, 26(2), 256-278. 
Marodin, G. A., Tortorella, G. L., Frank, A. G., \& Godinho Filho, M. (2017). The moderating effect of Lean supply chain management on the impact of Lean shop floor practices on quality and inventory. Supply Chain Management: An International Journal, 22(6), 473-485.

Mason-Jones, R., Naylor, B., \& Towill, D. R. (2000). Lean, agile or leagile? Matching your supply chain to the marketplace. International Journal of Production Research, 38(17), 4061-4070.

Mason-Jones, R., \& Towill, D. R. (1999). Total cycle time compression and the agile supply chain. International Journal of Production Economics, 62(1), 61-73.

Milgrom, P., \& Roberts, J. (1995). Complementarities and fit strategy, structure, and organizational change in manufacturing. Journal of Accounting and Economics, 9(2-3), 179-208.

Mittal, V. K., Sindhwani, R., Kalsariya, V., Salroo, F., Sangwan, K. S., \& Singh, P. L. (2017). Adoption of integrated lean-green-agile strategies for modern manufacturing systems. Procedia CIRP, 61, 463-468.

Mor, R. S., Bhardwaj, A., Singh, S., \& Sachdeva, A. (2019). Productivity gains through standardization-ofwork in a manufacturing company. Journal of Manufacturing Technology Management, 30(6), 899-919.

*Motadel, M., Toloie-Eshlaghy, A., \& Halvachi-Zadeh, D. (2011). Assessment of supply chain agility in the automotive industry of Tehran. European Journal of Scientific Research, 61(2), 210-229.

Moyano-Fuentes, J., Bruque-Cámara, S., \& Maqueira-Marín, J. M. (2019). Development and validation of a lean supply chain management measurement instrument. Production Planning and Control, 30(1), $20-32$.

Moyano-Fuentes, J., Maqueira-Marín, J. M., Martínez-Jurado, P. J., \& Sacristán-Díaz, M. (2021). Extending lean management along the supply chain: Impact on efficiency. Journal of Manufacturing Technology Management, 32(1), 63-84.

Moyano-Fuentes, J., Martínez-Jurado, P. J., Maqueira-Marín, J. M., \& Bruque-Cámara, S. (2012). Impact of use of information technology on lean production adoption : Evidence from the automotive industry. International Journal of Technology Management, 57(1/2/3), 132-148.

Naylor, J. B., Naim, M., \& Berry, D. (1999). Leagility: Integrating the lean and agile manufacturing paradigms in the total supply chain. International Journal of Production Economics, 62, 107-118.

Novais, L., Maqueira Marín, J. M., \& Moyano-Fuentes, J. (2020). Lean production implementation, cloudsupported logistics and supply chain integration: Interrelationships and effects on business performance. International Journal of Logistics Management, 31(3), 629-663.

Núñez-Merino, M., Maqueira-Marín, J. M., Moyano-Fuentes, J., \& Martínez-Jurado, P. J. (2020). Information and digital technologies of industry 4.0 and lean supply chain management : a systematic literature review. International Journal of Production Research, 58(16), 5034-61.

*Oh, S., Ryu, Y. U., \& Yang, H. (2019). Interaction effects between supply chain capabilities and information technology on firm performance. Information Technology and Management, 20(2), 91-106.

Okoli, C., \& Schabram, K. (2011). A guide to conducting a systematic literature review of information systems research. Sprouts: Working Papers on Information Systems, 10(26), 1-49.

Pagliosa, M., Tortorella, G., \& Ferreira, J. C. E. (2021). Industry 4.0 and lean manufacturing: A systematic literature review and future research directions. Journal of Manufacturing Technology Management, 32(3), 543-569.

*Panichayakorn, T., \& Jermsittiparsert, K. (2019). Mobilizing organizational performance through robotic and artificial intelligence awareness in mediating role of supply chain agility. International Journal of Supply Chain Management, 8(5), 757-768.

Paul, S. K., Asian, S., Goh, M., \& Torabi, S. A. (2019). Managing sudden transportation disruptions in supply chains under delivery delay and quantity loss. Annals of Operations Research, 273(1-2), 783-814.

*Paulraj, A., \& Chen, I. (2007). Strategic buyer-supplier relationships, information technology and external logistics integration. Journal of Supply Chain Management, 43(2), 2-15.

Ponomarov, S. Y., \& Holcomb, M. C. (2009). Understanding the concept of supply chain resilience. The International Journal of Logistics Management, 20(1), 124-143.

*Pool, J. K., Jamkhaneh, H. B., Tabaeeian, R. A., Tavakoli, H., \& Shahin, A. (2018). The effect of business intelligence adoption on agile supply chain performance. International Journal of Productivity and Quality Management, 23(3), 289-306.

Powell, T. C., \& Dent-Micallef, A. (1997). Information technology as competitive advantage: The role of human, business, and technology resources. Strategic Management Journal, 18(5), 375-405.

Qi, Y., Zhao, X., \& Sheu, C. (2011). The impact of competitive strategy and supply chain strategy on business performance: The role of environmental uncertainty. Decision Sciences, 42(2), 371-389.

Qrunfleh, S., \& Tarafdar, M. (2013). Lean and agile supply chain strategies and supply chain responsiveness: The role of strategic supplier partnership and postponement. Supply Chain Management: An International Journal, 18(6), 571-582.

*Qrunfleh, S., \& Tarafdar, M. (2014). Supply chain information systems strategy: Impacts on supply chain performance and firm performance. International Journal of Production Economics, 147, 340-350. 
*Qrunfleh, S., Tarafdar, M., \& Ragu-Nathan, T. S. (2012). Examining alignment between supplier management practices and information systems strategy. Benchmarking, 19(4), 604-617.

Queiroz, M. M., Pereira, S. C. F., Telles, R., \& Machado, M. C. (2021). Industry 4.0 and digital supply chain capabilities: A framework for understanding digitalisation challenges and opportunities. Benchmarking, 28(5), 1761-1782.

*Rahimi, A., Raad, A., Alem Tabriz, A., \& Motameni, A. (2019). Providing an interpretive structural model of agile supply chain practices. Journal of Modelling in Management, 15(2), 661-684.

Rojo, A. G. B., Perez-Arostegui, M. N., \& Llorens-Montes, J. (2020). Ambidexterity and IT competence can improve supply chain flexibility? A resource orchestration approach. Journal of Purchasing and Supply Management, 26(2), 100610.

Rungtusanatham, M. J., Choi, T. Y., Hollingworth, D. G., Wu, Z., \& Forza, C. (2003). Survey research in operations management: Historical analyses. Journal of Operations Management, 21(4), 475-488.

*Samdantsoodol, A., Cang, S., Yu, H., Eardley, A., \& Buyantsogt, A. (2017). Predicting the relationships between virtual enterprises and agility in supply chains. Expert Systems with Applications, 84, 58-73.

*Samizadeh, R., Aghagoli, S., \& Vatankhah, S. (2019). The effect of IT integration on improving agility, integration and performance of supply chain. International Journal of Advanced Operations Management, $11(1-2), 126-141$.

*Sangari, M. S., \& Razmi, J. (2015). Business intelligence competence, agile capabilities, and agile performance in supply chain: An empirical study. International Journal of Logistics Management, 26(2), $356-380$.

Sangwa, N. R., \& Sangwan, K. S. (2018). Leanness assessment of organizational performance : A systematic literature review. Journal of Manufacturing Technology Management, 29(5), 768-788.

*Schniederjans, D. G., Ozpolat, K., \& Chen, Y. (2016). Humanitarian supply chain use of cloud computing. Supply Chain Management: An International Journal, 21(5), 569-588.

Secchi, R., \& Camuffo, A. (2016). Rolling out lean production systems: A knowledge-based perspective. International Journal of Operations \&amp; Production Management, 36(1), 61-85.

Seuring, S., \& Gold, S. (2012). Conducting content-analysis based literature reviews in supply chain management. Supply Chain Management: An International Journal, 17(5), 544-555.

Seuring, S., Yawar, S. A., Land, A., Khalid, R. U., \& Sauer, P. C. (2021). The application of theory in literature reviews-illustrated with examples from supply chain management. International Journal of Operations and Production Management, 41(1), 1-20.

Shah, R., \& Goldstein, S. M. (2006). Use of structural equation modeling in operations management research: Looking back and forward. Journal of Operations Management, 24(2), 148-169.

*Shahin, A., Pool, J. K., \& Khalili, A. (2016). Investigating the impact of RFID technology utilisation on supply chain and performance with a case study in Iran's manufacturing industries. International Journal of Procurement Management, 9(6), 751-770.

Sharma, N., Sahay, B. S., Shankar, R., \& Sarma, P. R. S. (2017). Supply chain agility: Review, classification and synthesis. International Journal of Logistics Research and Applications, 20(6), 532-559.

*Sheel, A., \& Nath, V. (2019). Effect of blockchain technology adoption on supply chain adaptability, agility, alignment and performance. Management Research Review, 42(12), 1353-1374.

Sirmon, D. G., Hitt, M. A., Ireland, R. D., \& Gilbert, B. A. (2011). Resource orchestration to create competitive advantage: Breadth, depth, and life cycle effects. Journal of Management, 37(5), 1390-1412.

*So, S., \& Sun, H. (2010). Supplier integration strategy for lean manufacturing adoption in electronic-enabled supply chains. Supply Chain Management: An International Journal, 15(6), 474-487.

*So, S., \& Sun, H. (2011). An extension of IDT in examining the relationship between electronic-enabled supply chain integration and the adoption of lean production. International Journal of Production Research, 49(2), 447-466.

Stewart, M., \& Ivanov, D. (2019). Design redundancy in agile and resilient humanitarian supply chains. Annals of Operations Research, In press. Doi: https://doi.org/10.1007/s10479-019-03507-5.

*Swafford, P. M., Ghosh, S., \& Murthy, N. (2008). Achieving supply chain agility through IT integration and flexibility. International Journal of Production Economics, 116, 288-297.

*Tarafdar, M., \& Qrunfleh, S. (2017). Agile supply chain strategy and supply chain performance: Complementary roles of supply chain practices and information systems capability for agility. International Journal of Production Research, 55(4), 925-938.

Teece, D. J. (2007). Explicating dynamic capabilities: The nature and microfoundations of (sustainable) enterprise performance. Strategic Management Journal, 28(13), 1319-1350.

Thomé, A. M. T., Scavarda, L. F., \& Scavarda, A. J. (2016). Conducting systematic literature review in operations management. Production Planning and Control, 27(5), 408-420.

Thöni, A., \& Tjoa, A. M. (2017). Information technology for sustainable supply chain management: A literature survey. Enterprise Information Systems, 11(6), 828-858. 
Tranfield, D., Denyer, D., \& Smart, P. (2003). Towards a methodology for developing evidence-informed management knowledge by means of systematic review. British Journal of Management, 14(3), 207-222.

*Vagnoni, E., \& Khoddami, S. (2016). Designing competitivity activity model through the strategic agility approach in a turbulent environment. Foresight, 18(6), 625-648.

*Vickery, S. K., Droge, C., Setia, P., \& Sambamurthy, V. (2010). Supply chain information technologies and organisational initiatives: Complementary versus independent effects on agility and firm performance. International Journal of Production Research, 48(23), 7025-7042.

*Wamba, S. F., \& Akter, S. (2019). Understanding supply chain analytics capabilities and agility for data-rich environments. International Journal of Operations and Production Management, 39(6), 887-912.

*Wamba, S. F., Dubey, R., Gunasekaran, A., \& Akter, S. (2020). The performance effects of big data analytics and supply chain ambidexterity: The moderating effect of environmental dynamism. International Journal of Production Economics, 222, 107498.

*Yang, J. (2014). Supply chain agility: Securing performance for Chinese manufacturers. International Journal of Production Economic, 150, 104-113.

Yu, W., Jacobs, M. A., Chavez, R., \& Feng, M. (2017). The impacts of IT capability and marketing capability on supply chain integration: A resource-based perspective. International Journal of Production Research, 55(14), 4196-4211.

*Yusuf, Y. Y., Gunasekaran, A., Adeleye, E. O., \& Sivayoganathan, K. (2004). Agile supply chain capabilities: Determinants of competitive objectives. European Journal of Operational Research, 159(2), 379-392.

*Zelbst, P. J., Green, K. W., Sower, V. E., \& Abshire, R. D. (2014). Impact of RFID and information sharing on JIT, TQM and operational performance. Management Research Review, 37(11), 970-989.

Zhang, X., van Donk, D. P., \& van der Vaart, T. (2011). Does ICT influence supply chain management and performance?: A review of survey-based research. International Journal of Operations and Production Management, 31(11), 1215-1247.

Publisher's Note Springer Nature remains neutral with regard to jurisdictional claims in published maps and institutional affiliations. 